\title{
"IF YOU CAN'T MEASURE IT, YOU CAN'T MANAGE IT": TRANSBOUNDARY WATERS, GOOD GOVERNANCE AND DATA \& INFORMATION SHARING \& EXCHANGE
}

\author{
Richard K. Paisley and Taylor W. Henshaw ${ }^{1}$
}

\section{INTRODUCTION}

In governing transboundary waters it is critical to establish and maintain exchange agreements and networks for data and information sharing among stakeholder basin states and institutions. This practice maximizes securitization by building trust, which translates to unified and adaptive governance of transboundary waters. ${ }^{2}$ Data and information sharing is considered a precondition for data integration, joint modeling, and common monitoring protocols ${ }^{3}$ and is also widely seen as a basis or

1. Global Transboundary International Waters Governance Initiative, University of British Columbia IAR, Vancouver, Canada V6T 1Z2. The authors gratefully acknowledge the support and encouragement of a wide range of individuals and institutions obtained through a Global Environment Facility (GEF) project entitled Good Practices and Portfolio Learning in GEF Transboundary Freshwater and Marine Legal and Institutional Frameworks. This three-year multi-donor project was dedicated to facilitating good governance and more effective decision making in international waters through the identification, collection, adaptation, and replication of beneficial practices and lessons learned from international experiences. The project also facilitated dialogue among individuals and organizations engaged in governance within, and between, freshwater, groundwater and marine international waters with particular emphasis on "South-South" cooperation and learning. The key measurable benefit of the project is ensuring that various lessons leamed from multi-country experiences, including identification of areas where problems and delays are commonly experienced, are assimilated by various target audiences in a meaningful way through experiential learning. See Legal Frameworks, INTERNATIONAL WATERS LEARNING EXCHANGE \& RESOURCE NETWORK, http://iwlearn.net/publications/legalframeworks (last visited Jan. 5, 2014, archived at http://perma.cc/LD98-HCUN). This paper draws in part on materials originally researched and prepared in 2009 by Richard Kyle Paisley and Dr. Abdulkarim Seid for the Water Resources Planning and Management (WRPM) division of the Nile Basin Initiative.

2. UN WATER TASK FORCE ON TRANSBOUNDARY WATERS, TRANSBOUNDARY WATERS: SHARING BENEFITS, SHARING RESPONSIBILITIES 3, 10 (2008), archived at http://perma.cc/CZH3-CJPJ; see generally Andrea K. Gerlak et al., Water Resources Data and Information Exchange in Transboundary Water Treaties, 11 INT'L ENVTL. AGREEMENTS: POL., L., \& ECON. 179 (2011); see also United NaTions EduCaTIONAL, SCIENTIFIC CUltural ORganization (UNESCO), United Nations World Water DEVElopment REPORT 3: WATER IN A CHANGING WORLd (2009), available at http://unesdoc.unesco.org/images/0018/001819/181993e.pdf.

3. See generally B.C. Karkkainen, Managing Transboundary Aquatic Ecosystems: Lessons from the Great Lakes, 19 PAC. MCGeorge GloBal BuS. \& DEV. L.J. 209 (2006); see generally G.T. Raadgever et al., Assessing Management Regimes in Transboundary 
starting point for more comprehensive cooperation regarding shared resources. ${ }^{4}$ Absent such sharing and exchange, it becomes extremely difficult for basin states and institutions to manage water uses, formulate basin-wide policies, and take steps to minimize floods, droughts, and pollution. ${ }^{5}$

This Article presents case studies on data and information sharing and exchange practices in twenty-four transboundary waters situations. In attempting to find an idealized approach to this aspect of good governance of transboundary waters, the authors conclude with thoughts on the possible scope and content of a functional data and information sharing agreement.

\section{TRANSBOUNDARY WATERS}

For the purposes of this paper, transboundary waters are waters that are shared by two or more sovereign states and include international freshwater, international groundwater, and international Large Marine Ecosystems (LMEs) ${ }^{6}{ }^{\text {The }}$ world's 263 or more transboundary freshwater river basins and lakes alone cover nearly one half of the world's land surface, account for an estimated 60 percent of global freshwater flow, and support roughly 2 billion people globally. ${ }^{7}$

Transboundary waters link populations within and between countries, as well as foster hydrological and economic interdependencies. ${ }^{8}$ The

River Basins: Do They Support Adaptive Management? 13:1 ECOLOGY AND SOCIETY 14 (2008).

4. See generally Jonathan L. Chenoweth \& Eran Feitelson, Analysis of Factors Influencing Data and Information Exchange in International River Basins: Can Such Exchanges be Used to Build Confidence in Cooperative Management?, 26 WATER INT'L 499 (2001).

5. See generally Gabriel Eckstein, Water Scarcity, Conflict and Security in a Climate Change World: Challenges and Opportunities for International Law and Policy, 27 WISCONSIN. INTL. LAW J. 409 (2010).

6. LMEs are regions of ocean space of $200,000 \mathrm{~km} 2$ or greater that encompass coastal areas from river basins to estuaries to the outer margins of a continental shelf or the seaward extent of a predominant coastal current. LMEs are defined by ecological criteria, including bathymetric, hydrographic, productivity, and trophically linked populations. KENNETH Sherman, Large Marine Ecosystems of the World: Trends IN ExPloitation, PROTECTION, AND RESEARCH (2003). See also UNESCO INTERGOVERNMENTAL OCEANOGRAPHIC COMMISSION TECHNICAL SERIES. (2008); INTERNATIONAL UNION FOR CONSERVATION of Nature and Natural Resources, Sustaining the World's LaRge ECOSYSTEMS iii (Kenneth Sherman et al. eds., 2009), archived at http://perma.cc/82FGM39U; United Nations EnV'T Program, The GEF UNEP LaRge Marine Ecosystem RePort: A PERSPECtive ON Changing Conditions in LMEs of tHe World's Regional SEAS 3 (Kenneth Sherman and Gotthilf Hempel eds., 2008).

7. See UN WATER TASK FORCE ON TRANSBOUNDARY WATERS, supra note 2 , at 1.

8. Id.; see also Int'L Bureau of the Permanent Court of arbitration, The RESOlUtion OF INTERNATIONAL WATER Disputes: PAPERS EMANATING FROM THE SIXTH PCA INTERnATIONAl LAW SEMINAR November 8, 2002 at xxi; see also Aaron T. Wolf, Development and Transboundary Waters: Obstacles and Opportunities, in River Basin 
utilization of transboundary waters is also a potential source of friction among basin states vying for scarce resources. Sharing water resources creates intricate diplomatic challenges ... "[often linking] states in asymmetric upstream/downstream relationships, at a time when pressures on the world's water supplies are increasing substantially."9 Good governance of transboundary waters is critical to ensure stability, security and prosperity in regions that increasingly depend on these waters.

\title{
III. DATA AND INFORMATION
}

\section{"If you can't measure it, you can't manage it"10}

[D]ata and information exchange in international river basins requires both political agreement and technical proficiency. Such data collection incurs costs, and establishing exchange mechanisms requires transaction costs. These are likely to vary significantly as a function of the relations between the countries, as well as a function of the structure and independence of water institutions within them. ${ }^{11}$

Chenoweth and Feitelson conclude that joint data collection, data sharing, or exchange is likely only if all parties perceive that benefits will outweigh the costs; and several factors can affect the perceived costs and benefits. The authors classify these factors as primary or secondary:

\begin{abstract}
[Primary (or basic) factors are] those aspects relating to a river or groundwater basin, which essentially cannot be changed by internal or external forces and must, therefore, be accepted as forming the basic context of the secondary (or derived factors). . . . Secondary factors are issues that the individual countries, or collectively the basin as a whole, have at least limited power to modify. It is these factors that will largely determine whether effective data and information exchange can actually occur. ${ }^{12}$
\end{abstract}

Management: Its Role in Major Water Infrastructure Projects, in WORLD COMMISSION ON DAMS THEMATIC REV. 30 (2000).

9. Ken Conca et al., Global Regime Formation or Complex Institution Building? The Principled Content of International River Agreements, 50 INT'L STUD. Q. 263 (2006).

10. This ubiquitous quote is ascribed to various sources, including Peter Drucker. See Lucas Coffeen, "If You Can't Measure it, You Can't Manage it", MARKetCulture Blog (Mar. 20, 2009), http://blog.marketculture.com/2009/03/20/if-you-cant-measure-it-you-cantmanage-it-peter-drucker/, archived at $\mathrm{http}: / /$ perma.cc/3VVC-SGHT.

11. Jonathan L. Chenoweth \& Eran Feitelson, Analysis of Factors Influencing Data and Information Exchange in International River Basins: Can Such Exchanges be Used to Build Confidence in Cooperative Management?, 26 WATER INT'L 499 (2001) (alteration added).

12. See id. for an in depth discussion of these factors. While some primary and secondary factors are closely related in some river basins, the factors are considered separate 
Table 1: Factors that Affect the Perceived Costs and Benefits of Data Exchange ${ }^{13}$

\begin{tabular}{|c|c|}
\hline PRIMARY FACTORS & $\begin{array}{l}\text { - } \text { - Absence of Legacies of Mistrust } \\
\text { - Political Stability } \\
\text { - Common Language and Culture } \\
\text { - Sufficient Levels of Economic Development } \\
\text { - Increasing Water Resources Stress }\end{array}$ \\
\hline $\begin{array}{l}\text { SECONDARY } \\
\text { FACTORS }\end{array}$ & $\begin{array}{l}\text { - Perception by Basin Countries that Cooperation } \\
\text { is of Mutual Benefit } \\
\text { - External Pressure and Funding for Cooperative } \\
\text { Initiatives } \\
\text { - Comparable Levels of Institutional Capacity } \\
\text { - Popular and Political Concern About Water } \\
\text { Resources Management } \\
\text { - Existence of a Functional Formal or Informal } \\
\text { Cooperative Arrangement }\end{array}$ \\
\hline
\end{tabular}

\section{Data, Information Sharing, Exchange, and International Law}

Transboundary waters have "characteristics that make their conservation and management particularly challenging, the most notable of which is the tendency for regional politics to regularly exacerbate the already difficult task of understanding and managing complex natural systems." 14

There are several rules of international law of a general and fundamental nature that govern the conduct of states in relation to transboundary watercourses. ${ }^{15}$ The most basic of these are the following:

when they can operate independently of the other or where the relative importance of the two factors can be significantly different (alteration added).

13. Chenowith \& Feitelson, supra note 11.

14. Alex Grzybowski et al., Beyond International Water Law: Successfully Negotiating Mutual Gains Agreements for International Watercourses, 22 PAC. MCGEORGE GLOBAL BUS \& DEV. L.J. 139, 140 (2010).

15. See Richard K. Paisley, International Water Law, Transboundary Water Resources and Development Aid Effectiveness, 1 Indian Jurid. Review 67 (2004). For background on the law of transboundary waters, see generally Aaron T. Wolf et al., International River Basins of the World, 15 INT'L J. OF WATER RES. DEV. 387 (1999); see also STEPHEN MCCAFFREY, THE LAW OF INTERNATIONAL WATERCOURSES (2d ed. 2007). 
- States are to use an international watercourse in a way that is "equitable and reasonable" vis-à-vis other states sharing the watercourse.

- States are to take "all appropriate measures" to prevent causing "significant harm" to co-riparian states.

- States are to "consult" with the other international watercourse states and provide "timely notification" about any new use or change in an existing use of an international watercourse that could have significant adverse effects on co-riparian states, along with relevant technical information. ${ }^{16}$

Beyond customary international legal obligations lie treaties and other agreements that are negotiated between states in an effort to address particular watercourse management issues, to clarify how customary obligations will be met, and in some cases to jointly develop opportunities that neither state could fully capitalize on if acting independently. ${ }^{17}$

The 1997 United Nations Convention on Law of the NonNavigational Uses of International Watercourses recognizes that the exchange of data and information is a necessary prerequisite for good governance. ${ }^{18}$ Article 9 requires basin states to regularly exchange data and information on the condition of the watercourse, in particular that of a hydrological, meteorological, hydrogeological, and ecological nature or related to water quality and related forecasts. ${ }^{19}$ The Convention also allows states to request information that is not currently available while providing compensation to the state procuring the data. ${ }^{20}$

The general obligation of transboundary water states to exchange information is further affirmed in various ministerial declarations from international waters conferences. These include: the Declaration of the

16. Grzybowski et al., supra note 14 .

17. Id.

18. Convention on Law of the Non-navigational Uses of International Watercourses, G.A. Res. 51/49, U.N. Doc. A/51/49, art. 9 (May 21, 1997), archived at http://perma.cc/DDX8-ZSJ9.

19. Id.

20. Id. In 1997, the United Nations Convention on the Non-Navigational Uses of International Water Courses was adopted by the United Nations General Assembly by a vote of 103 for, 3 against, with 27 abstentions and 33 members absent. GA Res. 51/229, U.N. Doc. A/Res/51/229 (July 8, 1997). It has since become the principal instrument with which states may negotiate and develop water resources along international rivers and through which international law may be applied. Though extremely holistic in content, taking into account the basin wide approach and the precautionary principle, the Convention has yet to be ratified by a sufficient number of countries to enter into force. The UN Watercourses Convention counts today 27 contracting states -8 short of the number required for entry into force. See $U N$ Watercourses Convention, WWF GLOBAL, http://wwf.panda.org/what_we_do/how_we_ work/policy/conventions/water_conventions/un_watercourses_convention/ (last visited on Jan. 7, 2014, archived at http://perma.cc/NA48-572A). 
United Nations Conference on the Human Environment (encouraging the collection and exchange of information through joint mechanisms); ${ }^{21}$ Dublin Statement of the International Conference on Water and the Environment (recommending information exchange as a means of minimizing conflict over shared resources); ${ }^{22}$ and the Kyoto Ministerial Declaration of the $3^{\text {rd }}$ World Water Forum (encouraging information exchange as a mechanism to mitigate natural disasters). ${ }^{23}$

Certain resolutions of international organizations further affirm the general obligation to exchange information. These include the United Nations Economic Commission for Europe Decision on International Cooperation on Shared Water Resources, article 13 (encouraging members to carry out joint data collection projects), ${ }^{24}$ Draft Principles of Conduct for the Guidance of States in the Conservation and Harmonious Exploitation of Natural Resources Shared by Two or More States; ${ }^{25}$ and Co-operation in the Field of the Environment Concerning Natural Resources Shared by Two or More States. ${ }^{26}$

Numerous international resolutions also include a duty to exchange information on transboundary watercourses. These include: the Institut de Droit International Resolution on the Pollution of Rivers and Lakes and International Law, article VII (encouraging the exchange of data on pollution and the coordination of programs designed to generate data about the basin), ${ }^{27}$ the International Law Association New York Resolution, article 3 (recommending that "[c]o-riparian states ... make available to the appropriate agencies of the United Nations and to one another, hydrological, meteorological[,] and economic information, particularly as to streamflow, quantity and quality of water, rain and snowfall, [and] water tables and underground water movements"), ${ }^{28}$ and the International Law

21. United Nations Conference on the Human Environment, Stockholm, Swed., June 516, 1972, Declaration of the United Nations Conference on the Human Environment, 21st plen. mtg. (June 16, 1972, archived at http://perma.cc/7V6L-XH4A).

22. International Conference on Water and the Environment, Dublin, Ir., Jan.26-31, 1992, The Dublin Statement on Water and Sustainable Development, (Jan. 31, 1992, archived at $\mathrm{http}: / /$ perma.cc/9M26-LZCP).

23. Third World Water Forum, Kyoto, Japan, 28, Mar. 23, 2003, archived at http://perma.cc/UW9D-UJTS.

24. Convention on the Protection and Use of Transboundary Watercourses and International Lakes, Mar. 17, 1992, 1936 U.N.T.S. 269, archived at http://perma.cc/9ABTG27P.

25. U.N. Environment Programme, Rep. of the Governing Council on its 6th Sess., May 9-25, 1978, U.N. Doc, A33/25 GAOR, 33d Sess., Supp. No. 25 (1978).

26. G.A. Res. 34/186, at 128, U.N. Doc. A/RES/34/186 (Dec. 18, 1979).

27. Inst. de Droit Int'l, The Pollution of Rivers and Lakes and International Law, Sess. of Athens, 15th Comm'n, (Sept. 12, 1979).

28. Food \& Agric. Org. of the U. N. [FAO], Sources of International Law, Some General Conventions, Declarations, Resolutions and Decisions adopted by International Organizations, International Non-Governmental Institutions, International and Arbitral 
Association, Helsinki Rules, article $\mathrm{XXIX},{ }^{29}$ relating information exchange to the mitigation of water disputes. Article XXIX specifies:

With a view to preventing disputes from arising between
basin states as to their legal rights or other interest, it is
recommended that each basin state furnish relevant and
reasonably available information to the other basin states
concerning the waters of a drainage basin within its
territory and its use of, and activities with respect to each
waters.

This statement affirms not only the interconnection between other key legal principles and the principle of information exchange, but also the legal obligation of riparian states to provide data to co-basin states. By enhancing cooperation and trust, the sharing of information eases the way for discussions on particularly contentious matters, such as allocation.

In theory and practice, the above instruments establish an international legal obligation to share and exchange information regarding shared transboundary waters. ${ }^{31}$

\section{Sources of Data and Information Exchange $e^{32}$}

In the context of transboundary waters, there are three broad categories of sources for data and information:

- National (private): refers to data and information generally available in national agencies of riparian states. While certain rules are to be followed to obtain access to data and information for "national" use, special arrangements may be required to obtain access by "outsiders."

- $\quad$ Shared: refers to data and information available to all riparian states that is compiled through the consent and participation of the riparian states. The fact that the data and information is "shared" by the states signifies that they are mutually agreed upon by the riparian states.

- Public domain: data and information in the public domain are usually available to practically anyone. Examples of such data and information include satellite images and derived products obtainable from the worldwide web, as well as information released for public "consumption." Data and information sharing and exchange in

Tribunals on International Water Resources, FAO Legis. Study 65 at 289 (1998), available at ftp://ftp.fao.org/docrep/fao/005/w9549E/w9549e04.pdf (alteration added).

29. Id. at 299.

30. Id.

31. See MCCAFFREY, supra note 15.

32. The support and encouragement of Dr. Abdulkarim Seid, who assisted with this section, is gratefully acknowledged. 
transboundary waters is usually governed by written agreements. These agreements recognize different classes of users and the sensitivity of the data and information. In the case of international waters, agreements are usually needed on data and information exchange or sharing to define the terms (or modalities) under which access can be granted and to whom.

In the context of freshwater transboundary waters, Burton and Molden developed a classification of development phases. ${ }^{33}$ This classification system is used here to illustrate how information and data needs evolve with growing development, thus requiring an increased allocation of resources. According to this classification, transboundary waters fall in any of three phases: development, utilization, and reallocation. ${ }^{34}$

Transboundary drainage basins are said to be in a development phase if the amount of naturally occurring water is not a limiting factor for development. ${ }^{35}$ In such a situation, growth in demand for water is the primary driving force for the development of infrastructure. ${ }^{36}$ In the second phase, the utilization phase, a significant proportion of available resources have been committed to use. ${ }^{37}$ Governance in such basins shifts more toward effective utilization from available facilities, such as through the reuse of drainage water and demand management. ${ }^{38}$ With further development of resources as demand grows, a situation can be reached where most of the usable water has been committed. ${ }^{39}$ This phase is termed reallocation. ${ }^{40}$ The main focus of governance in transboundary drainage basins in this third phase is making the "best" use of available water, which may lead to reallocating resources from lower to higher value uses. ${ }^{41}$

The types of data and information needed change as more water and other resources become committed to various uses and the focus of governance moves more toward demand management. ${ }^{42}$ In Table 2, Burton and Molden summarize the main types of data and information usually thought to be required at different levels of development in a transboundary

33. Martin Burton \& David Molden, Making Sound Decisions: Information Needs for Basin Water Management, in IRRIGATION AND RIVER BASIN MANAGEMENT: OPTIONS FOR GOVERNANCE AND INSTITUTIONS 51 (Mark Svendsen ed., 2005).

34. Id. at 58.

35. Id.

36. Id.

37. Id.

38. Id.

39. Id.

40. Id.

41. Id.

42. Id. 
freshwater drainage basin. ${ }^{43}$

Table 2: Development stages and data and information requirements in an international drainage basin. ${ }^{44}$

\begin{tabular}{|c|c|c|}
\hline Data needs & $\begin{array}{c}\text { Typical } \\
\text { data collected }\end{array}$ & $\begin{array}{l}\text { Developments in } \\
\text { information processes }\end{array}$ \\
\hline \multicolumn{3}{|c|}{ Infancy: Localized use only } \\
\hline $\begin{array}{l}\text { Rudimentary, limited to } \\
\text { water levels and extent of } \\
\text { flooding }\end{array}$ & $\begin{array}{l}\text { Flood water levels, } \\
\text { flooded areas (through } \\
\text { experience) }\end{array}$ & $\begin{array}{l}\text { Demarcation (and } \\
\text { avoidance) of flooded } \\
\text { areas, correlation of } \\
\text { flood extent and flood } \\
\text { levels }\end{array}$ \\
\hline \multicolumn{3}{|c|}{$\begin{array}{l}\text { Development: Water allocation is supply focused; Data collected and used } \\
\text { by small number of agencies for specific uses and projects }\end{array}$} \\
\hline $\begin{array}{l}\text { Availability of water } \\
\text { during the year and extent } \\
\text { of agricultural land; } \\
\text { Main focus is on surface } \\
\text { water, though some } \\
\text { interest in groundwater for } \\
\text { urban and irrigation } \\
\text { development; } \\
\\
\text { For initial planning for } \\
\text { river basin development. }\end{array}$ & $\begin{array}{l}\text { Project-wise collection } \\
\text { of river flow and } \\
\text { quality data; } \\
\text { Climatic data, } \\
\text { particularly rain-fall; } \\
\text { Land use in riverine } \\
\text { plains and extent of } \\
\text { agricultural land } \\
\text { Topographic surveys; } \\
\text { Aerial photography; } \\
\text { Land ownership, } \\
\text { traditional/existing } \\
\text { water rights. }\end{array}$ & $\begin{array}{l}\text { Initial data collection } \\
\text { systems established for } \\
\text { individual projects; } \\
\text { gradually these are linked } \\
\text { up and coordinated by } \\
\text { the development } \\
\text { agency(s); } \\
\text { Basin-wide hydrometric } \\
\text { stations established to } \\
\text { gather base data. }\end{array}$ \\
\hline
\end{tabular}

43. Id. at 59 .

44. Id. 
Utilization: Water allocation is supply-focused; Data related processes and procedures well established

\begin{tabular}{|c|c|c|}
\hline $\begin{array}{l}\text { Detailed knowledge of the } \\
\text { available water resources, } \\
\text { both surface and } \\
\text { groundwater, particularly } \\
\text { over-year to establish } \\
\text { storage patterns for } \\
\text { reservoirs and recharge } \\
\text { patterns for groundwater; } \\
\text { For river basin master } \\
\text { planning. }\end{array}$ & $\begin{array}{l}\text { River flow data } \\
\text { throughout the basin; } \\
\text { Climatic data } \\
\text { throughout the basin; } \\
\text { Land ownership and } \\
\text { traditional/existing } \\
\text { water rights; } \\
\text { Groundwater level and } \\
\text { quality; } \\
\text { Some monitoring of } \\
\text { pollution levels. }\end{array}$ & $\begin{array}{l}\text { Data collection } \\
\text { procedures standardized } \\
\text { and co-coordinated; } \\
\text { Procedures established } \\
\text { for monitoring pollution } \\
\text { levels; } \\
\text { Procedures established } \\
\text { for monitoring } \\
\text { groundwater depth and } \\
\text { quality; } \\
\text { Publication of water } \\
\text { resources and climatic } \\
\text { data; } \\
\text { Development of simple } \\
\text { water resources models } \\
\text { for river basins }\end{array}$ \\
\hline
\end{tabular}

Reallocation and restoration:

Demand and supply focused; Data related processes and procedures refined and more widely disseminated

To obtain detailed

knowledge of the annual

and inter-year water

resource situation both for

supply and demand;

To monitor and control

water abstraction by users; Groundwater level and

To make projections of supply and demand;

For water resources modeling, using remote sensing and GIS;

River flow and water Hydrometric network

quality data throughoutextended and automated the basin;

Climatic data

throughout the basin; Groundwater monitoring network extended; quality;

Pollution levels;

Water abstraction by Further computerization all users; of data collection, Data for prosecution of processing and analysis; over-abstraction and/or 


\begin{tabular}{|l|l|l|}
\hline $\begin{array}{l}\text { For scenario analysis; } \\
\text { For river basin master } \\
\text { planning; }\end{array}$ & $\begin{array}{l}\text { pollution; } \\
\text { To refine and update } \\
\text { supply and demand } \\
\text { projections, scenario } \\
\text { analysis; }\end{array}$ & $\begin{array}{l}\text { Development of } \\
\text { sophisticated water } \\
\text { perspective of different } \\
\text { resource models for river } \\
\text { basins, with refinement } \\
\text { to become an operational } \\
\text { tool; }\end{array}$ \\
$\begin{array}{l}\text { To formulate rules for } \\
\text { allocation of water during } \\
\text { droughts / shortages. }\end{array}$ & $\begin{array}{l}\text { Water needs for } \\
\text { various environmental } \\
\text { processes. }\end{array}$ & $\begin{array}{l}\text { Remote sensing } \\
\text { incorporated into water } \\
\text { management and } \\
\text { decision making; }\end{array}$ \\
& & $\begin{array}{l}\text { Publication of water } \\
\text { resources supply and } \\
\text { demand information; }\end{array}$ \\
& & $\begin{array}{l}\text { Analysis and } \\
\text { presentation of data for a } \\
\text { wider range of } \\
\text { stakeholders; }\end{array}$ \\
& & $\begin{array}{l}\text { Scenario analysis to } \\
\text { enable participation in } \\
\text { decision-making. }\end{array}$ \\
\hline
\end{tabular}

Every transboundary drainage basin is unique and may not lend itself to be strictly classified into any one of these phases. However, as more water and related resources are committed to use, less purely "supplyoriented" measures will be adequate to achieve efficient utilization. ${ }^{45}$ Utilization usually requires more sophisticated tools, detailed information, and data than what would be required in a relatively undeveloped situation where resource availability has not yet become a constraint or limiting factor for development. ${ }^{46}$

Data and information exchange can develop as an organic process. "The process may commence with the exchange of independent data, followed by standardization of data, and then joint collection and monitoring. ${ }^{, 47}$ Further along the progression is the exchange of forecasting

45. Id.

46. $I d$.

47. Richard K. Paisley \& Glen Hearns, Some Observations From Recent Experiences With the Governance of International Drainage Basins, in Symposium, Precious, Worthless, or Incalculable: The Value and Ethic of Water, vol. 2, Ctr. for Water Law \& Policy and Int'1 
and water use plans. Eventually, common planning can occur. It is hoped that riparian actors ultimately come to an agreement on the equitable allocation of consumptive use, pollution, and dispute resolution mechanisms. Such an agreement could create a framework for developing resources in one nation at the joint cost and for the joint benefit of several coordinated administrative structures.

\section{DATA AND INFORMATION SHARING AND EXCHANGE CASE STUDIES}

The following twenty-four case studies provide practical examples of data and information sharing and exchange in the context of governance over transboundary waters. These case studies can be used to facilitate good governance and more effective decision making in transboundary waters, through adaptation and replication.

\section{Wider Caribbean}

In article 13 of the Cartagena Convention, ${ }^{48}$ the Contracting Parties agreed to cooperate, both with each other and with relevant international and regional organizations, in "scientific research, monitoring, and the exchange of data and other scientific information relating to the purposes of th[e] Convention. ${ }^{, 49}$ In addition, article 17 of the Specially Protected Areas and Wildlife (SPAW) Protocol ${ }^{50}$ calls upon the Contracting Parties to develop "scientific, technical[,] and management-oriented research" on protected areas and threatened or endangered species and their habitats. ${ }^{51}$ The Contracting Parties are also encouraged to consult with one another and with relevant organizations to: identify protected areas and species in order to conduct research and monitoring programs; assess the effectiveness of measures enacted to implement management and recovery plans; exchange information and coordinate research and monitoring programs;

Ctr. for Arid and Semi-Arid Land Studies, Tex. Tech Univ. (A.C. Corrêa \& Gabriel Eckstein eds., 2006).

48. Convention for the Protection and Development of the Marine Environment of the Wider Caribbean, Mar. 24, 1983, 1506 U.N.T.S 157 [hereinafter Cartagena Convention], archived at http://perma.cc/3H2V-W6ZU. The Contracting Parties to the Cartagena Convention include: the United States, Antigua \& Barbuda, Bahamas, Barbados, Belize, Colombia, Costa Rica, Cuba, Dominica, Dominican Republic, France, Grenada, Guatemala, Guyana, Jamaica, Mexico, Netherlands, Nicaragua Panama, St. Kitts \& Nevis, St. Lucia, St. Vincent, Trinidad \& Tobago, United Kingdom, and Venezuela.

49. Id. (alteration added).

50. Final Act of the Conference of Plenipotentiaries for the Adoption of the Annexes to the Protocol Concerning Specially Protected Areas and Wildlife in the Wider Caribbean Region, June 11, 1991, archived at http://perma.cc/5FKP-P63Z [hereinafter SPAW Protocol]. The Contracting Parties of the SPAW Protocol include: United States, Barbados, Belize, Colombia, Cuba, Dominican Republic, France, Guyana, Netherlands, Panama St. Lucia, St. Vincent, Trinidad \& Tobago, and Venezuela.

51. Id. (alteration added). 
and to standardize the procedures used for collecting, reporting, archiving, and analyzing scientific and technical information. ${ }^{52}$ The Caribbean Regional Coordinating Unit (CAR/RCU) is also intended to serve as a forum for collecting, reviewing, and distributing information on relevant studies, publications, and the results of work conducted under the framework of the Cartagena Convention and its Protocols. ${ }^{53}$ The Caribbean Environment Programme (CEP) manages and/or contributes to numerous databases related to the marine and coastal environment in the Wider Caribbean Region. ${ }^{54}$ The SPAW Species Database, which is hosted and maintained by the CEP, contains both taxonomic information and distribution data on protected species of marine and coastal flora and fauna. ${ }^{55}$

Other relevant databases include: the Caribbean Marine Protected Area (MPA) (information on protected coastal areas in thirty-four countries and territories); ${ }^{56}$ the Solid Waste and Marine Litter Database $;{ }^{57}$ the Global Environment Facility Integrating Watershed and Coastal Areas Management in Caribbean Small Island Developing States Project Databases (GEF-IWCAM) ${ }^{58}$ INFOTERRA (the United Nation Environment Program (UNEP) Global Environmental Information Exchange Network); ${ }^{.9}$ and UNEP State of the Environment Reports (SOER) (information on the environmental health of countries and regions) ${ }^{60}$ The Contracting Parties also agreed to develop information systems and networks to promote the exchange of information and facilitate

52. Id. sub 2-4.

53. UNEP-Caribbean Regional Coordinating Unit, THE CARIBBEAN ENV'T Programme, http://www.cep.unep.org/about-cep/unep-car-rcu/unep-caribbean-regionalcoordinating-unit (last visited Jan. 6, 2014, archived at http://perma.cc/VVX2-CDAC).

54. CEP-Databases, The CaribBean ENV'T PROGRAMME, http://www.cep.unep.org/ publications-and-resources/databases (last visited on Jan. 6, 2014, archived at http://perma.cc/Z47U-EGF5).

55. SPAW Protocol, supra note 50, annex. I-III.

56. Welcome, Caribbean MPA: A Database of the Wider Caribbean's Marine PROTECTED AREAS, http://campam.gcfi.org/CaribbeanMPA/CaribbeanMPA.php (last visited Jan. 6, 2014, archived at http://perma.cc/8JWQ-68CR).

57. Solid Water and Marine Litter, THE CARIBBEAN ENV'T PROGRAMme http://www.cep.unep.org/publications-and-resources/marine-and-coastal-issues-links/solidwaste-and-marine-litter (last visited Jan. 6, 2014, archived at http://perma.cc/U5ZQ-EQXL).

58. Databases - IWCAM, INTEgrating WATERSHEd AND COASTAL AREAS MGMT. IN CARIBBEAN SMALl ISLAND DEVELOPING STATES, http://cep.unep.org/iwcam/database (last visited Jan. 6, 2014, archived at http://perma.cc/64F6-8C88).

59. UNEP Infoterra, ThE CENT. Eur. ENVTL. DATA ReQuest Facility, $\mathrm{http}: / / \mathrm{www} . c e d a r . a t /$ sitemap.htm?page=/unep/infoterra/ (last visited Jan. 6, 2014, archived at http://perma.cc/U6VC-CSPZ).

60. "UNEP regularly produces State of the Environment Reports for individual countries and regions. These SOERs provide crucial information on the current status of the environmental health of many different countries." See CEP-Databases, supra note 54. 
the implementation of the Land-Based Sources (LBS) Protocol. ${ }^{61}$

\section{Amazon Basin}

In the Amazon Basin, member states of the Amazon Cooperation Treaty Organization (ACTO) ${ }^{62}$ have a duty to "maintain a permanent exchange of information and cooperation among themselves," as well as with other agencies operating in the Amazon River Basin. ${ }^{63}$ This sharing of information is reflected in the multiple memoranda of understanding that ACTO has entered into with other regional and worldwide bodies such as the Andean Community and the Inter-American Development Bank. ${ }^{64}$ The Member States also agree to exchange information on flora, fauna, and diseases in the Amazonian territory and to make an annual report on the conservation measures adopted. ${ }^{65}$ Distributed to all Member States, the ACTO Annual Action Plan informs all states of the Permanent Secretariat's activities by describing the programs and projects that are underway. ${ }^{66}$ The Action Plan describes the duration of the program or project, estimated costs, and projected sources of funding. The coordinators of active projects must report back to the Permanent Secretariat on established indicators designed to assess the progress towards the achievement of project goals. The Permanent Secretariat publishes Annual Reports on projects. ${ }^{67}$

\section{International Commission for the Conservation of Atlantic Tunas (ICCAT)}

Every two years, the International Commission for the Conservation

61. Protocol Concerning Pollution from Land-Based Sources and Activities to the Convention for the Protection and Development of the Marine Environment of the Wider Caribbean Region, art. VIII, Oct. 6, 1999 archived at http://perma.cc/3CMQ-B979. The Contracting Parties of the LBS Protocol include the following countries: United States, Antigua \& Barbuda, Bahamas, Belize, France, Guyana, Panama, St. Lucia, and Trinidad \& Tobago.

62. See Portal otCa, ACTO: Amazon CoOperation Treaty Organization, http://otca.info/portal/ (last visited Jan. 7, 2014, archived at http://perma.cc/DQ87-7GWN). The Member States of the Amazon Cooperation Treaty and the ACTO are Bolivia, Brazil, Colombia, Ecuador, Guyana, Peru, Suriname, and Venezuela.

63. Treaty for Amazonian Cooperation art. XV, July 3, 1978, 1202 U.N.T.S. 71, archived at http://perma.cc/JCV3-8RZ5.

64. See, e.g., OTCA, SeCRETARIA GENERAL, COMUNIDAD ANDINA, MEMorandum of UNDERSTANDING, archived at $\mathrm{http} / / /$ perma.cc/X5NU-VMZH.

65. Treaty for Amazonian Cooperation, supra note 63, art. VII.

66. See Plan de Trabajo Anual, OTCA, http://otca.info/portal/plano-trabalho.php?p=agd (last visited Jan. 7, 2014, archived at http://perma.cc/HQ3Y-34AH).

67. See, e.g., amazon Cooperation Treaty Organization, Work Plan 2013: B. COORDINATING OFFICE OF INDIGENOUS AFFAIRS (2004), archived at http://perma.cc/7X2TNF2Y. 
of Atlantic Tunas (ICCAT) ${ }^{68}$ submits a report on its work and findings, which is transmitted by the Executive Secretary to all Contracting Parties of the Commission, the Food and Agriculture Organization of the United Nations (FAO), and any government or international organization invited to send observers to the meeting. ${ }^{69}$ The Council, Panels, and other subsidiary bodies of ICCAT also adopt reports at the end of each meeting, which are then submitted to the appropriate parent body. ${ }^{70}$ Generally speaking, ICCAT collects two main types of data: fishery-dependent and fisheryindependent. ${ }^{71}$ ICCAT generally relies on fishery-dependent data sources such as logbooks, observer programs, port sampling, factory/market sampling, and international trade (import/export) statistics. ${ }^{72}$ Fisheryindependent data includes research vessel surveys and other studies like tagging programs. ${ }^{73}$ ICCAT also maintains a number of statistical databases containing data on fleet characterization (number and type of fishing vessels); nominal catch (by species, region, gear, flag); catch and effort (fishing fleet, time, gear and time and area strata); and fish size (size samples and catch-at-size estimates). ${ }^{74}$

68. BASIC TEXTS, INT'L COMM'N. FOR THE CONSERVATION OF ATLANTIC TUNAS art. III (2007), archived at http://perma.cc/5588-5B8C. ICCAT has 48 Contracting Parties: United States, Albania, Algeria, Angola, Barbados, Belize, Brazil, Canada, Cape Verde, China, Côte d'Ivoire, Croatia, Egypt, Equatorial Guinea, Eur. Comty., France (St. Pierre \& Miquelon), Gabon, Ghana, Guatemala Guinea, Honduras, Iceland, Japan, South Korea, Libya, Mauritania, Mexico, Morocco, Namibia, Nicaragua, Nigeria, Norway, Panama, Philippines, Russsia, St. Vincent, Sao Tome \& Principe, Senegal, Sierra Leone, South Africa, Syria, Trinidad \& Tobago, Tunisia, Turkey, United Kingdom (Overseas Territories), Uruguay, Vanuatu, and Venezuela.

69. See ICCAT Biennial Reports, INT'L COMM'N. FOR THE CONSERVATION OF ATLANTIC TUNAS, http://www.iccat.int/en/pubs_biennial.htm (last visited Jan. 7, 2014, archived athttp://perma.cc/V9Z9-BWEY).

70. BASIC TEXTS, supra note 68 , at Rule 15; the reports are available on the ICCAT website. See ICCAT Biennial Reports, supra note 69.

71. See ICCAT MANUAL, INT'L COMM'N. FOR THE CONSERVATION OF ATlantic TUNAS, sec. 1.2 , archived at $\mathrm{http}: / /$ perma.cc/FF7G-DR8M.

72. Id.

73. Id. Tunas and billfishes are tagged in order to learn more about their movements, migrations, stock structure, growth, population size, mortality, schooling behavior, and physiology. Tagging is also used to study the effects of fishing patterns on the fish and fisheries. Currently, ICCAT has developed a cooperative tagging program in the Atlantic Ocean and adjacent seas, through which various countries are participating. Tagging, INT'L COMM'N. FOR THE CONSERVATION OF ATLANTIC TUNAS, http://www.iccat.int/en/TagDesc.htm (last visited Jan. 7, 2014, archived at http://perma.cc/7PYY-7TSF).

74. Access to ICCAT Statistical Databases, INT'L COMM'N. FOR THE CONSERVATION OF ATLANTIC TUNAS, http://www.iccat.int/en/accesingdb.htm (last visited Jan. 7, 2014, archived at http://perma.cc/57FS-KMUX); ICCAT MANUAL, supra note 71, sec. 1.3. 


\section{Rio Grande/Rio Bravo}

Data on water flow and reservoir condition is collected and updated daily on the International Boundary and Water Commission (IBWC) website. ${ }^{75}$ Flow of the Rio Grande and Tributaries and Related Data, an IBWC Bulletin, annually publishes information on collated stream gauging record and records of waters in storage, rainfall and evaporation stations, and measurements of the quality of waters. ${ }^{76}$ Data on water quality and quantity is available on IBWC's Geographic Information System. ${ }^{77}$

\section{Mediterranean Sea}

Under the Barcelona Convention for the Protection of the Mediterranean Sea Against Pollution, the Contracting Parties are called upon to promote cooperation among themselves regarding environmental impact assessment procedures for activities in their jurisdiction that are likely to have significant adverse effects on: the marine environment of other Contracting Parties, or areas beyond their jurisdiction. ${ }^{78}$ This cooperation is to be achieved through notification, exchange of information, and consultation. ${ }^{79}$ In addition, the Protocols require the Contracting Parties to share specific information relevant to their subject matters: ${ }^{80}$

- The Dumping Protocol requires each Contracting Party to report dumping permits issued and the actual dumping that occurs. ${ }^{81}$ The

75. Rio Grande Basin Conditions, INT'L BOUNDARY \& WATER COMM'N: U. S. \& MEX., http://www.ibwc.gov/Water_Data/Reports/RG_Flow_data.html (last visited Jan. 7, 2014, archived at http://perma.cc/L8AH-E99U).

76. Water Bulletins, INT'L BOUNDARY \& WATER COMM'N: U. S. \& MEX., http://www.ibwc.state.gov/Water_Data/water_bulletins.html (last visited Jan. 7, 2014, archived at http://perma.cc/FM5A-T28N). The IBWC Member States are the United States and Mexico.

77. Geographic Information System (GIS) Program, INT'L BOUNDARY \& WATER COMM'N: U. S. \& MEX., http://www.ibwc.gov/GIS_Maps/GIS_Program.html (last visited Jan. 7, 2014, archived at http://perma.cc/JP3Q-DUNS).

78. Barcelona Convention for the Protection of the Mediterranean Sea Against Pollution, Feb. 16, 1976, 1102 U.N.T.S. 27 [hereinafter Barcelona Convention], archived at http://perma.cc/P6E9-KBPS. The Contracting Parties of the Barcelona Convention are Albania, Algeria, Bosnia \& Herzegovina, Croatia, Cyprus, Egypt, Eur., France, Greece, Israel, Italy, Lebanon, Libya, Malta, Monaco, Montenegro, Morocco, Slovenia, Spain, Syria, Tunisia, and Turkey. Id.

79. Id. arts. $10,11$.

80. Protocol for the Protection of the Mediterranean Sea Against Pollution Resulting from Exploration and Exploitation of the Continental Shelf and the Seabed and its Subsoil arts. 24(3), 25, Oct. 14, 1994 [hereinafter Offshore Protocol].

81. See Protocol for the Prevention of Pollution of the Mediterranean Sea by Dumping from Ships and Aircraft art. 12, Feb. 16, 1976 ("Each Party undertakes to issue instructions to its maritime inspection ships and aircraft and to other appropriate services to report to its 
Dumping Protocol also provides that each Contracting Party shall, if it considers it appropriate, report suspicions of illegal dumping to other concerned Parties. ${ }^{82}$

- The Emergency Protocol obliges its Contracting Parties to exchange information, through the Regional Activity Centre (RAC) in Malta, about domestic regulations, responsible authorities, and best practices regarding the prevention of pollution and emergency response. ${ }^{83}$ The Emergency Protocol further requires Contracting Parties to warn the nearest coastal state (and other Parties likely to be affected) of incidents that may result in pollution. ${ }^{84}$ Contracting Parties must also inform each other of their planned response to a pollution incident. ${ }^{85}$

- The Offshore Protocol (which is not yet in force) would require Contracting Parties to ensure that persons on offshore installations follow similar procedures. ${ }^{86}$

- The Hazardous Wastes Protocol requires its Contracting Parties to report to the Secretariat, as soon as possible, information relating to illegal traffic in hazardous waste. ${ }^{87}$ Contracting Parties must also share annual statistics on waste generation and transfer. ${ }^{88}$

- The Specially Protected Areas and Biodiversity Protocol calls upon Contracting Parties to regularly exchange information about the characteristics of protected areas and species and to communicate, at the earliest opportunity, information on any situation that might endanger protected ecosystems. ${ }^{89}$

- The Integrated Coastal Zone Management Protocol (which is not yet

authorities any incidents or conditions in the Mediterranean Sea area which give rise to suspicions that dumping in contravention of the provisions of this Protocol has occurred or is about to occur. That Party shall, if it considers it appropriate, report accordingly to any other Party concerned.").

82. Protocol for the Prevention of Pollution of the Mediterranean Sea by Dumping from Ships and Aircraft or Incineration at Sea, arts. 10, 12, June 10, 1995 [hereinafter Dumping Protocol] (not yet in force).

83. See Protocol Concerning Cooperation in Preventing Pollution from Ships and, in Cases of Emergency, Combating Pollution of the Mediterranean Sea art. 8, Feb. 16, 1976, archived at $\mathrm{http}: / /$ perma.cc/RJ9E-TK9G.

84. Id. art. 9.

85. Protocol Concerning Co-operation in Combating Pollution of the Mediterranean Sea by Oil and Other Harmful Substances in Cases of Emergency arts. 7, 9, 10, Feb. 16, 1976, archived at http://perma.cc/9HR4-9QU9 [hereinafter Emergency Protocol] (entered into force Feb. 12, 1978).

86. Offshore Protocol, supra note 80 , arts. 16, 17 (art. 16 specifically requires the application of the Emergency Protocol).

87. See Protocol on the Prevention of Pollution of the Mediterranean Sea by Transboundary Movements of Hazardous Wastes and Their Disposal arts. 9(8), 11, Oct. 1, 1996 [hereinafter Hazardous Wastes Protocol], archived at http://perma.cc/8F6Z-CRJV.

88. Id. arts. 8(2), 9(6).

89. Protocol Concerning Specialty Protected Areas and Biological Diversity in the Mediterranean, art. 21(1)-(2), June 10, 1995, archived at http://perma.cc/Z5P5-HK9J [hereinafter Specially Protected Areas and Biodiversity Protocol]. 
in force) would require Contracting Parties to assess and report the status of coastal erosion and to share information about major natural disasters. $^{90}$

Under article 11 of the Barcelona Convention the Contracting Parties agree to go "as far as possible to cooperate ... in the fields of science and technology and to exchange data as well as other scientific information for the purpose of this Convention." cooperation in their respective domains. For example, according to article 7(f) of the Emergency Protocol, the Contracting Parties are obligated to share information about "new ways in which pollution of the sea by oil and hazardous and noxious substances may be avoided, new measures for combating pollution, new developments in the technology of conducting monitoring and the development of research programmes." ${ }^{92}$ Under article 20 of the Specially Protected Areas and Biodiversity Protocol, the Contracting Parties are called upon to coordinate, to the extent possible, their research and monitoring of protected areas and species. ${ }^{93}$ Article 8 of the Hazardous Wastes Protocol mandates cooperation in the development and implementation of clean production methods. ${ }^{94}$

Furthermore, article 22 of the Offshore Protocol and article 25(2) of the Integrated Coastal Zone Management Protocol (which are not yet in force) call for cooperation in the research of new technology and emergency procedures and in research on integrated coastal zone management, respectively. ${ }^{95}$ The Protocols expressly provide that progress and lessons learned in implementation will be shared at regular meetings with the respective Contracting Parties. ${ }^{96}$ The Contracting Parties have also begun to coordinate national library resources related to marine science. ${ }^{97}$

90. Protocol on Integrated Coastal Zone Management, arts. 23(4), 24(2), Jan. 21, 2008, archived at http://perma.cc/D3PY-PZDE [hereinafter ICZM Protocol].

91. Convention for the Protection of the Marine Environment and the Coastal Region of the Mediterranean art. 11, June 10,1995, archived at http://perma.cc/6LD7-KDCE.

92. Protocol Concerning Cooperation in Preventing Pollution from Ships and, in Cases of Emergency, Combating Pollution of the Mediterranean Sea, supra note 83, art. 7(f).

93. Specially Protected Areas and Biodiversity Protocol, supra note 89, art. 20(1).

94. Hazardous Wastes Protocol, supra note 87, art. 8(1).

95. Offshore Protocol, supra note 80, art. 22; ICZM Protocol, supra note 90, art. 25.

96. See Dumping Protocol, supra note 82, art. 14(2); Emergency Protocol, supra note 85 art. 18(2); Protocol Concerning Pollution from Land-Based Sources, supra note 61, arts. 13, 14(2); Specially Protected Areas and Biodiversity Protocol, supra note 89, art. 26(2); Offshore Protocol, supra note 80, art. 25; Hazardous Wastes Protocol, supra note 87, art. 11; ICZM Protocol, supra note 90, art. 33 (requiring Parties at regular meetings "to consider the efficiency of the measures adopted").

97. See European Ass'N of Aquatic Sci. Libraries \& Info. Ctr. (EURASliC) MEDITERRANEAN SPECIAL INTEREST GRP., REPORT OF THE FIRST WORKSHOP/MEETING OF THE MEDITERRANEAN MARINE AND AQUATIC SCIENCE LIBRARIES AND INFORMATION CENTRES NETWORK (2008). 
In 1996, the Contracting Parties and the EU commissioned the development of a data coordinating structure, which led to the Euro Mediterranean (Water) Information System (EMWIS) ${ }^{98}$ The decision making and operational structure of EMWIS is independent of the Barcelona Convention structure, but its objectives include developing national water information systems and efforts to transfer know-how in the water sector. ${ }^{99}$ The Protocols also establish principles to harmonize environmental policies, including the precautionary principle, ${ }^{100}$ the "polluter pays" principle, ${ }^{101}$ and a technology-based approach considerate of sustainable development needs. ${ }^{102}$ To facilitate such harmonization, article 14(2) of the Barcelona Convention suggests that the Secretariat may assist Contracting Parties in drafting environmental legislation that is in compliance with the Barcelona Convention and its Protocols. ${ }^{103}$ The Protocols generally establish or call for the development of baseline measures to be implemented in national regulations, but do not require absolute harmonization of law. ${ }^{104}$ The Barcelona Convention and certain

98. The Euro-MediterRanean Conference on Water Mgmt. Held in Marseilles (1996), archived at http://perma.cc/XQY9-AWBJ (containing decisions adopted by the Ministers and Heads of delegation); EURO-MEdITERRANEAN WATER INFO. SYS., EMWIS HANDY GUIDE, (2000) [hereinafter EMWIS], archived at http://perma.cc/3SLW-WRBF.

99. See Decision-Making Level, EURO-MEDITERRANEAN INFORMATION SYSTEM ON KNOW-HOW IN THE WATER SECTOR, http://www.semide.net/overview/fol226852/fol 720468 (last updated Sep. 8, 2011, archived at http://perma.cc/MPM9-4VEP); Operational Level, EURO-MEDITERRANEAN INFORMATION SYSTEM ON KNOW-HOW IN THE WATER SECTOR, http://www.emwis.org/overview/fol226852/fol335117 (last updated Sep. 8, 2011, archived at http://perma.cc/K32W-3YC2); Orientations, EURO-MEDITERRANEAN INFORMATION SYSTEM ON KNOW-HOW IN THE WATER SECTOR, http://www.semide.net/overview/ fol350157/doc064667 (last updated on Feb. 9, 2008, archived at http://perma.cc/QKD8GNX3).

100. See, e.g., U.N. Env't Progamme (UNEP), Rep. of the 16th Ordinary Meeting of the Contracting Parties to the Convention for the Protection of the Marine Env't and the Coastal Region of the Mediterranean and its Protocols, at Annex I p. 3, Annex III, Five-Year Programme of Work 2010-2013, Appendix 1, at 4, UNEP (DEPI)/MED IG.19/8 (2009); Dumping Protocol, supra note 82, Annex III, II B(9); Emergency Protocol, supra note 85, pmbl.; Hazardous Wastes Protocol, supra note 87, art. 8(3); Specially Protected Areas and Biodiversity Protocol, supra note 89, pmbl.

101. See, e.g., Offshore Protocol, supra note 80, art. 27; Rep. of the 15th Ordinary Meeting of the Contracting Parties to the Convention for the Protection of the Marine Env't and the Coastal Region of the Mediterranean and its Protocols, Annex V, Decision IG 17/4 (and Appendix), UNEP (DEPI)/MED IG.17/10 (2008): Guidelines for the Determination of Liability and Compensation for Damage Resulting from Pollution of the Marine Environment in the Mediterranean Sea Area ("Decision IG 17/4"), at 136, para. 9.

102. See, e.g., Emergency Protocol, supra note 85, pmbl.; Land-Based Sources Protocol, supra note 61, arts. 7(2)-(3), and Annex IV; Offshore Protocol, supra note 80, art. 3.

103. Barcelona Convention, supra note 78, art. 14(2).

104. See, e.g., Dumping Protocol, supra note 82, arts. 11, 13; Land-Based Sources Protocol, supra note 61, arts. 6, 7 and Annex II; Offshore Protocol, supra note 80, arts. 10, 
Protocols promote harmonization by requiring technical assistance to developing countries. ${ }^{105}$

\section{Caspian Sea}

The Framework Convention for the Protection of the Marine Environment of the Caspian Sea, the "Tehran Convention," contains a number of articles dealing specifically with the exchange of information among the Member States, ${ }^{106}$ cooperation on environmental policies, and harmonization of national laws. ${ }^{107}$ The Member States are directed to harmonize their national laws and to work together in order to develop specific rules and standards designed to protect the environment of the Caspian Sea, including for joint development of an action plan to help implement the objectives of the Tehran Convention. ${ }^{108}$ The Member States are called upon to: (a) collect and exchange data concerning the sources of pollution in the Caspian Sea; (b) develop programs to monitor water quality and quantity; (c) develop contingency plans for pollution emergencies; (d) implement emission and discharge limits; (e) establish water quality objectives and criteria; and (f) develop harmonized programs to reduce pollution loads from municipal and industrial points, as well as from diffuse sources. ${ }^{109}$ The Member States are also to cooperate on research and development concerning techniques for the prevention, control, and reduction of pollution in the Caspian Sea. ${ }^{110}$ The gathered information and any resulting reports are exchanged among the Member States through the Secretariat. ${ }^{111}$ The Member States, in conjunction with the Secretariat, are to endeavor to provide public access to this information and to the action plans developed by the Member States. ${ }^{112}$

\section{Danube River Basin}

Overall, information sharing, exchange, and harmonization have been

23(2); Specially Protected Areas and Biodiversity Protocol, supra note 89, arts. 16, 27; ICZM Protocol, supra note 90, arts. 4(3), 8(2)(a).

105. See Specially Protected Areas and Biodiversity Protocol, supra note 89, art. 22; Offshore Protocol, supra note 80, art. 24; Hazardous Wastes Protocol, supra note 87, art. 10; see also ICZM Protocol, supra note 90, art. 26.

106. Framework Convention for the Protection of the Marine Environment of the Caspian Sea, arts. 18-21, Nov. 4, 2003, [hereinafter Tehran Convention], archived at http://perma.cc/HL24-E8HW. The Caspian littoral states, all of whom have signed and ratified the Tehran Convention, are: Azerbaijan, the Islamic Republic of Iran, Kazakhstan, the Russian Federation and Turkmenistan.

107. See generally Id.

108. Id. art. 18.

109. Id. art. 18.

110. Id. art. 20.

111. Id. art. 21.

112. Id. arts. $20-21$. 
primary objectives of the International Commission for the Protection of the Danube River (ICPDR) from its inception. The Contracting Parties to the Danube River Protection Convention (DRPC) ${ }^{113}$ are required to report to the ICPDR on issues necessary for the ICPDR to comply with its tasks. ${ }^{114}$ Reports involve a variety of data and information, including information on other bilateral or multilateral agreements affecting the Danube; information on Contracting Parties' laws and regulations concerning the protection and water management of the river; communication concerning the domestic implementation of ICPDR decisions; designation of competent institutions for cooperation in the framework; and communication on planned activities likely to cause transboundary impacts. ${ }^{115}$ Similarly, as required by the ICPDR, the Contracting Parties are required to share with the other Contracting Parties any "reasonably available data" relating to: (a) the environmental conditions within the catchment area of the Danube River Basin; (b) the experience gained from the application of best techniques and results of research; (c) emission and monitoring data; (d) measures taken and planned to address transboundary impacts; (e) regulations for the discharge of waste water; and (f) accidents that involve substances hazardous to water. ${ }^{116}$ Additionally, the Contracting Parties are required to exchange information on regulations to harmonize emission limits. ${ }^{117}$ Moreover, provision is made to enable a Contracting Party to request data not available from another Contracting Party, on the condition that the requesting Contracting Party agrees to pay reasonable charges for collecting and processing such data or information. ${ }^{118}$

The objectives of the DRPC are also promoted by facilitating the exchange of "best available techniques" via promotion and commercial exchange, technical assistance, and joint training programs. ${ }^{119}$ In addition, the DRPC requires that the Contracting Parties make available all

113. Convention on Cooperation for the Protection and Sustainable Use of the Danube River, June 29, 1994 [hereinafter DRPC]. The DRPC and ICPDR Contracting Parties are Austria, Bosnia-Herzegovina, Bulgaria, Croatia, the Czech Republic, Germany, Hungary, Moldova, Montenegro, Romania, Serbia, the Slovak Republic, Slovenia, and Ukraine. The European Union is also a Contracting Party of the DRPC and ICPDR. In addition, countries in the catchment area of the Danube River Basin that cooperate with the ICPDR under the European Union Water Framework Directive include Albania, Italy, Macedonia, Poland, and Switzerland. See S. Paleari ET Al., Global INT'L Waters Assessment, TRansboundary Waters in the Black Sea-Danube Region; Legal and Fin. Implications (2005), archived at http://perma.cc/GDR7-SMFN.

114. DRPC, supra note 113, art. 10.

115. Id. Navigation on the Danube River is governed by the separate Danube Commission established by the Convention Regarding the Regime of Navigation on the Danube art. 10, Aug. 18, 1948, archived at $\mathrm{http} / / /$ perma.cc/G7PL-BF9N.

116. DRPC, supra note 113, art. 12.

117. Id.

118. Id. art. $12(3)$.

119. Id. arts. 12(1)-(4). 
information concerning the state or quality of the river environment "to any natural or legal person, with payment of reasonable charges, in response to any reasonable request." ${ }^{, 120}$ At the same time, the DRPC includes provisions for the protection of certain information and data, including personal data, industrial and commercial secrets, and information affecting public or national security. ${ }^{121}$ The DRPC also establishes obligations for coordinated or joint communication, warning and alarm systems, and obligations to consult on "ways and means of harmonizing domestic communication, warning and alarm systems and emergency plans." ${ }^{22}$ In this regard, Contracting Parties must supply competent authorities or points of contact for emergency events, including accidental pollution or critical water conditions such as floods and ice-hazards. ${ }^{123}$ Competent authorities identifying increases in hazardous substances, floods, or forecasts of icehazards are obligated to inform downstream states along the Danube River. ${ }^{124}$

There is also joint data collection, survey efforts, and a technical body - the Information Management and Geographical Information System Expert Group - which is charged with maintaining the overall data information system, created and instituted under the DRPC. ${ }^{125}$

\section{Franco-Swiss Genevese Aquifer}

The Genevese Aquifer Management Commission maintains an inventory of all waterworks and equipment, which is available to both Member States. ${ }^{126}$ Additionally, the volume of water extracted is to be recorded periodically and provided to the members of the Commission. ${ }^{127}$ The Commission also maintains a record of water level variations of the

120. Id. art. 14(1).

121. Id. arts. 12(5)-(6), 13, 14(3).

122. Id. art. $16(1)$.

123. Id. art. $16(2)$.

124. Id. art. 16(2)-(4).

125. Terms of Reference of the ad hoc Information Management and Geographical Information System Expert Group (ad hoc IM+GIS EG) of the ICPDR, sec. 2 (2006), archived at http://perma.cc/GRD3-3RWQ ("The overall objective of the ad hoc IM+GIS EG is to support ICPDR activities related to the operation and further development of the ICPDR information system. It comprises control over the development, implementation, testing and maintenance of a common Danube River Basin Geographical Information System (DRB GIS)."). The Member States are France (the Community of the Annemassienne Region, the Community of the Genevois Rural Districts, and the Rural District of Viry) and Switzerland (the Republic and Canton of Geneva).

126. Convention relative à la protection, à l'utilisation, à la réalimenation et au suivi de la nappe souterraine franco- suisse du Genevois art. 4, Dec. 182007 [hereinafter Franco-Swiss Genevese Aquifer Convention], archived at http://perma.cc/ME6M-FHFP (unofficial translation).

127. Id. arts. 5-6. 
aquifer, which is available to the parties on demand. ${ }^{128}$ Each user or group of users of the aquifer also informs the Commission of their estimated volume of extractions from the aquifer at the beginning of each year and their actual usage at the end of the year. ${ }^{129}$

\section{The Rhine}

Under article 5(1) of the Convention for the Protection of the Rhine, ${ }^{130}$ the Contracting Parties ${ }^{131}$ agreed to cooperate and inform one another of actions taken in their territory to protect the Rhine. ${ }^{132}$ In addition, under article 5(2), the Contracting Parties have also committed to implement international monitoring programs and studies of the Rhine ecosystem in their territories and to inform the International Commission for the Protection of the Rhine (ICPR) of the results of those studies and programs. ${ }^{133}$ The ICPR relies on the data collection and monitoring efforts of the Contracting Parties. For example, the Warning and Alert Plan allows the ICPR to gather information on water pollution levels collected by monitoring stations along the river, with more than 100 substances monitored. ${ }^{134}$

In addition, the Rhine 2020 program contains numerous targets designed to improve the health and ecological balance of the Rhine, and which call upon the Contracting Parties to work in collaboration in order to meet the stated goals of the program. ${ }^{135}$ In addition, as required by the European Water Framework Directive, an Internationally Coordinated Management Plan for the International River Basin District of the Rhine (Part A) was released in December 2009. ${ }^{136}$ The report contains the following discussion, as it pertains to the Rhine, of: (a) human activities and stresses; (b) a register of protection areas; (c) surveillance networks and results of surveillance programs; (d) environmental objectives and

128. Id. arts. 6.2, 7.2.

129. Id. arts. 9.1, 10.3 .

130. The Convention on the Protection of the Rhine art. 5, Apr. 12, 1999, archived at http://perma.cc/ME6M-FHFP.

131. The Member States are Germany, France, Luxembourg, the Netherlands, Switzerland, and the European Union. Id. pmbl.

132. The Convention on the Protection of the Rhine, supra note 130, art. 5(1).

133. Id. art. 5(2); see also Welcome, INT'L COMMISSION FOR THE PROTECTION OF THE RHINE, http://www.iksr.org/indexphp?id $=58 \& \mathrm{~L}=3 \& \mathrm{cHash}=455 \mathrm{fdab} 52 \mathrm{c}$ (last visited Jan. 9, 2014, archived at http://perma.cc/PU9J-P9J4).

134. See id.

135. INT'L Commission for the Protection of the Rhine, RhINe 2020: Programme on SUSTAINABLE DEVELOPMENT BALANCE 2000-2005, archived at http://perma.cc/43F6-4HVN.

136. INT'L COMMISSION FOR THE PROTECTION OF THE RHINE, INTERNATIONALlY CoOrdinated Mgmt. Plan for the Int'l River Basin District of the RhINe (2009), archived at http://perma.cc/89WA-HSDH. 
adjustments; (e) economic analysis; (f) summary of the program of measures; (g) a list of the program and management plans; and (h) other relevant items. ${ }^{137}$ There are also coordinated reports for the areas of operation in the Rhine international river basin district (the Alpenrhein/Bodensee, High Rhine, Upper Rhine, Neckar, Main, Middle Rhine, Mosel/Saar, Niederrhein, and the Delta Rhine), as well as national management plans for Switzerland, Liechtenstein, Austria, France, Germany (broken down by different regions in the country), Luxembourg, Belgium, and the Netherlands. ${ }^{138}$

\section{Abidjan Convention}

Under article 22 of the Abidjan Convention, ${ }^{139}$ the Contracting Parties ${ }^{140}$ should transmit to the UNEP reports on the measures they adopted in implementing the Convention and its Protocol(s).$^{141}$ In addition, each Contracting Party should also provide the UNEP, according to articles 12 and 3, respectively, with information concerning pollution emergencies and any additional agreements entered into concerning the protection of the marine and coastal environment in the Convention area. ${ }^{142}$ The UNEP, as the Secretariat, will send these reports to the other Contracting Parties, as required by article 16 of the Abidjan Convention. ${ }^{143}$ And according to article 13, the Contracting Parties should develop procedures to share information regarding their environmental assessments of potentially

137. Id. at 4-5.

138. Management Plan, ICPR Water Framework Directive, available at http://www.iksr.org/index.php?id=171\&L=3 (last visited Jan. 10, 2014, archived at http://perma.cc/G22W-ZUQY); InTERnationally CoORdinated Mgmt. Plan for the INT'L RIVER BASIN DISTRICT OF THE RHINE, supra note 136.

139. Convention for Co-operation in the Protection and Development of the Marine and Coastal Environment of the West and Central African Region arts. 3(1), 12, 22, Mar. 23, 1981 [hereinafter Abidjan Convention], archived at http://perma.cc/47SS-6UTD.

140. The Contracting Parties that have ratified the Abidjan Convention are Benin, Cameroon, the Republic of the Congo, Côte d'Ivoire, Gabon, Gambia, Ghana, Guinea, Liberia, Nigeria, Senegal, Sierra Leone, South Africa and Togo. Angola, Cape Verde, the Democratic Republic of the Congo, Equatorial Guinea, Guinea-Bissau, Mauritania, Namibia, and Sao Tome and Principe are located in the Abidjan Convention area, but have not yet ratified the Convention. InTERnational Waters GOVERnANCE, Member States, http://www.internationalwatersgovernance.com/abidjan-convention.html (last visited Jan. 1, 2012, archived at http://perma.cc/GLC7-794W). As part of a revitalization program for the Abidjan Convention, one of the focuses is on persuading these countries (through high-level delegation visits and support from the Secretariat) to ratify and accede to the Abidjan Convention. Relevant institutions are also allowed to accede to the Abidjan Convention. Id.

141. Convention for Co-operation in the Protection and Development of the Marine and Coastal Environment of the West and Central African Region, supra note 139, art. 22.

142. Id. arts. 3,12 .

143. Id. art. 16. 
harmful activity. ${ }^{144}$ Furthermore, as the Contracting Parties are meant to cooperate, according to article 14 of the Abidjan Convention, in the fields of scientific research and development, monitoring, and assessments of pollution in the Convention area, the Contracting Parties should exchange with each other relevant data and other scientific information related to the Abidjan Convention and its Protocol(s) ${ }^{145}$

In addition, under article 5 of the Protocol, each Contracting Party is also obligated to provide the Secretariat and the other Contracting Parties with information on its National Focal Point; its relevant laws, regulations, and other legal instruments; and its national marine emergency contingency plans. ${ }^{146}$ As part of the revitalization program, the stakeholders requested that each National Focal Point provide the Secretariat with reports on its national coastal and marine environment and on the status of its implementation of the relevant Abidjan Convention work programs. ${ }^{147}$ As part of the effort to revitalize the Abidjan Convention, one of the strategies is focused on enhancing the sharing among the Contracting Parties of reliable and up-to-date information, especially if the information could lead to a better understanding among the Contracting Parties of the benefits of the Abidjan Convention. ${ }^{148}$ The Abidjan Convention stakeholders recommended that the Contracting Parties adopt a specific information and data sharing policy to cover issues related to the sustainable development of the coastal and marine environment in the Convention area ${ }^{149}$ In addition, under the revitalization plan, the Contracting Parties asked the Secretariat to create a database and web-based information sharing system that would allow the Contracting Parties, as well as other stakeholders, to access information on the value and benefits of the Abidjan Convention. ${ }^{150}$

\section{Lake Tanganyika}

Article 19 directs the Contracting States of The Convention on the Sustainable Management of Lake Tanganyika to provide the public with "adequate information ... concerning the state of the Lake Basin, planned development activities, measures taken or planned to be taken to prevent, control and reduce adverse impacts, and the effectiveness of those

144. Id. art. 13 .

145. Id. art. 14 .

146. Id. art. 5.

147. Abidjan Convention Report Stakeholders MeEting, Held on Apr. 1-3, 2008, Dakar,'Senegal [hereinafter 2008 Stakeholders Report] 13, archived athttp://perma.ccl M3TU-FYMP.

148. Id.

149. Id. at 14-15.

150. ReP. Of the First Extraordinary MeEting of the Contracting Parties to the Abidjan Convention 21 (2008). 
measures." information available concerning: water and environmental quality objectives; compliance with permits; notifications concerning proposed activities likely to have trans-boundary adverse impacts; and environmental impact assessment reports concerning such activities. ${ }^{152}$ Article 20 addresses information exchange between the Contracting States, directing them to exchange data and information concerning sustainable management of the Lake Basin and the implementation of the Convention. ${ }^{153}$ Contracting States are also directed to employ "best efforts" to provide data or information that is requested, but not readily available. ${ }^{154}$ The Convention additionally obligates the Contracting States to report periodically to the Authority on certain measures relevant to the environmental management of the Lake Basin and the implementation of the Convention. ${ }^{155}$ Article 21 specifies that the Convention shall not affect the established rights or obligations of Contracting States to protect personal information, intellectual property, and confidential information. ${ }^{156}$ It also directs the Contracting States to respect the confidentiality of confidential information they receive. ${ }^{157}$

\section{Lake Victoria}

Article 24 of the Lake Victoria Basin Commission Protocol discusses the exchange of data and information, mandating that the Member States, ${ }^{158}$ on a regular basis, "exchange readily available and relevant data and information on existing measures on the condition of the natural resources of the Basin."159 If one Member State receives a request from another Member State for information that is not readily available, that Member State is obligated to use its best efforts to fulfil the request, but may condition its compliance upon receiving payment from the requesting Member State to cover the reasonable costs of collecting and processing the

151. The Convention on the Sustainable Management of Lake Tanganyika pmbl., June 12, 2003 archived at http://perma.cc/GL8G-J2ZQ; the Contracting States of the Convention are Burundi, the Democratic Republic of Congo (the DRC), Tanzania, and Zambia. Id. In November 2007, the DRC became the last of the Contracting States to ratify the Convention.

152. Id. art. 19.

153. Id. art 20.

154. Id. arts. 19-20.

155. Id. art. 22.

156. Id. art. 21.

157. Id.

158. The original Member States (Partner States) of both the LVBC and the LVFO are Kenya, Uganda and Tanzania. As Rwanda and Burundi acceded to the EAC in 2007, they are being integrated as members into the LVBC and the LVFO.

159. Protocol for Sustainable Development of Lake Victoria Basin art. 24, Nov. 29, 2003 [hereinafter LVBC Protocol], archived at http://perma.cc/46PX-Q8VC. 
relevant data. ${ }^{160}$ The Member States are also charged with facilitating collaboration in research and on the exchange of data, reports and information among stakeholders within the Member States. ${ }^{161}$ However, the exchange of information or data does not extend to information that is protected under the laws of the Member States or any international treaty to which a Member State is a party. ${ }^{162}$ Additionally, one of the functions of the LVBC Secretariat is to establish a regional database and to promote the sharing of information and the development of information systems and data exchange. ${ }^{163}$

In terms of harmonization, article 6(2) of the LVBC Protocol requires the Member States to take steps to harmonize their laws and policies through the institutional framework established under the LVBC Protocol. ${ }^{164}$ Accordingly, one of the functions of the LVBC listed under article 33(3) is to harmonize the policies, laws, regulations and standards of all of the Member States. ${ }^{165}$ More specifically, article 14 requires the Member States to harmonize their laws and regulations in order to conform to the guidelines formulated by the LVBC regarding environmental audits for operators of facilities within the Member States that are likely to have a significant impact on the environment; ${ }^{166}$ article $16(2)$ requires the Member States to "adopt standardized equipment and methods of monitoring natural phenomena;", 167 Article 25(1) requires the Member States to harmonize their water quality standards; ${ }^{168}$ and article 29 calls for the harmonization of infrastructure and services within the Member States. ${ }^{169}$

Article II(2) of the Lake Victoria Fisheries Convention calls for the harmonization of national measures in order to promote the sustainable utilization of the living resources of Lake Victoria. ${ }^{170}$ However, the LVFO Convention specifies that it does not infringe upon each Member State's sovereign powers regarding any of the areas covered by the LVFO Convention, and that each Member State remains free to adopt national laws that are more stringent or extensive than those required to fulfil its obligations to the LVFO. ${ }^{171}$ Under article XIII of the LVFO Convention,

160. Id.

161. Id.

162. Id.

163. Id. art. $42(\mathrm{c})$.

164. Id. art. $6(2)$.

165. Id. art. 33(3).

166. Id. art 14.

167. Id. art 16 .

168. Id. art $25(1)$.

169. Id. art 29.

170. Convention for the Establishment of the Lake Victoria Fisheries Organization arts. II(2), XII(4), June 30, 1994 [hereinafter LVFO Convention], archived at http://perma.cc/R7M2-4LY6.

171. Id. 
the Member States agreed to implement the decisions of the LVFO's governing bodies, in accordance with their respective constitutions and national legal frameworks. ${ }^{172}$ The Member States also agreed to adopt laws and regulations prohibiting the introduction of non-indigenous species into Lake Victoria, other than in accordance with a decision by the Council of Ministers. ${ }^{173}$

In terms of data sharing, each Member State is to provide the LVFO with access to "laws, regulations and all documents, data and reports pertaining to fish landings, stock assessments, living resources of Lake Victoria or any other matter which is the subject of resource management and utilization, and research" in furtherance of the objectives of the LVFO Convention. ${ }^{174}$ Additionally, each Member State must transmit to the LVFO an annual statement of the measures it has taken to implement the decisions of the Council of Ministers. ${ }^{175}$ Article XIV of the LVFO Convention requires the Member States, when a research program has been authorized by the LVFO, to grant access to the research teams to their national territories and territorial waters. ${ }^{176}$

\section{Niger Basin}

The Convention Creating the Niger Basin Authority (NBA) charges the Authority with harmonizing and coordinating national policies to develop the resources of the Niger Basin, and requires it to maintain permanent contact with the Member States ${ }^{177}$ to inform them of development plans in the Basin. ${ }^{178}$ In turn, the Member States undertake to inform the Executive Secretary of proposed projects in the Basin and agree not to undertake projects on portions of the Niger River in their jurisdiction that are likely to pollute the waters or adversely affect the biological characteristics of the flora or fauna. ${ }^{179}$ Outside the Convention framework, the NBA has established "national focal structures," or teams in each country, including a point of contact and various experts, to liaise and ensure proper communication between the Executive Secretariat and

172. Id. art. XIII.

173. Id.

174. Id. art. XII(5).

175. Id. art. XII(8).

176. Id. art. XIV.

177. Convention Creating the Niger Basin Authority art 3(2), Nov. 21, 1980, archived at http://perma.cc/XCJ9-DG2Q; the Niger Basin Authority Member States include the following riparian states of the Niger River: Niger, Benin, Chad, Guinea, Côte d'Ivoire, Mali, Nigeria, Cameroon and Burkina Faso. Id. pmbl.

178. Id.

179. Id. art. 4. 
national governments. ${ }^{180}$ The Water Charter of the Niger Basin provides for the exchange of information and obligates parties to consult and negotiate (if necessary) on the possible effects of planned measures. Member States are obligated to notify other Basin States (through the Executive Secretariat) prior to implementing measures that may have "significant adverse effects" on such states. ${ }^{181}$ The Executive Secretariat then refers the notification to the Permanent Technical Committee for an opinion. ${ }^{182}$ Notifying States must allow the Executive Secretariat a three-month period to review and evaluate the planned measures (such period may be extended), and during this period must provide requested data and information and refrain from implementing the planned measures. ${ }^{183}$ In the event a Notified State or the Executive Secretariat considers that the proposed measures are likely to have a significant harmful impact, the parties are to enter into consultations and negotiations. ${ }^{184}$

\section{Nubian Sandstone Aquifer System (NSAS)}

Data is consolidated in the Nubian Aquifer Regional Information System (NARIS) - which performs the following: (a) stores and documents different data relating to the NSAS; (b) processes, analyzes and displays the data; (c) prepares input parameters for different models of the Aquifer and provides comparisons of the results; and (d) provides a link among the Member States to exchange information. ${ }^{185}$ Additionally, the Member States have agreed to share information on yearly extractions, representative electrical conductivity measures, and water level measurements. ${ }^{186}$

\section{North Western Sahara Aquifer System (NWSAS)}

The original project for the North Western Sahara Aquifer System (NWSAS) called for the establishment of a "consultation mechanism" in

180. Peter Pieck, West Africa Sets an Example, Development and Cooperation, D+C, http://www.dandc.eu/en/article/international-management-river-niger (June 25, 2009, archived at http://perma.cc/DDE8-5R67).

181. The Water Charter of the Niger Basin arts. 19-20, 22, June 14, 2012 archived at http://perma.cc/7NK3-9KP2.

182. Id.

183. Id.

184. Id.

185. Agreement \#1, Terms of Reference For the Monitoring and Exchange of Groundwater Information of the Nubian Sandstone Aquifer System, Oct. 5, 2000, archived at http://perma.cc/VVD3-EKWZ; the Member States of the Joint Authority are Egypt, Libya, Sudan (since 1996), and Chad (since 1999). Id.

186. Agreement \#2, Terms of Reference for Monitoring and Data Sharing, Oct. 5, 2000, archived at http://perma.cc/9LN2-X62J. 
order to ensure that, at the conclusion of GEF project funding, there would be continued management of the shared water resources. ${ }^{187}$ This led to the creation of an Observatory for the Aquifer-Basin, which is shared by the three Member States. ${ }^{188}$ The Observatory for the Aquifer-Basin is responsible for technical and scientific issues related to the management of the shared waters, information exchange and consultation, and joint elaboration of simulation models. ${ }^{189}$ The Observatory of the Aquifer-Basin is also charged with a number of additional tasks, including data collection and the publication of relevant documents that synthesize data analysis on the exploitation of water resources and its implications. ${ }^{190}$

\section{Okavango River System}

The Permanent Okavango River Basin Water Commission (OKACOM) is authorized to appoint consultants to assist in gathering and processing information concerning any matter on which it is tasked with advising the Member States. ${ }^{191}$ A Member State may request that OKACOM provide such advice in the form of a written report signed by the leaders of each Member State's delegation. ${ }^{192}$ Each Member State's delegation is then responsible for submitting such reports to its respective government. ${ }^{193}$ During OKACOM's 16th Meeting, held in Gaborone, Botswana from 24-27 May 2010, OKACOM adopted a protocol to share information related to the Okavango River Basin..$^{194}$ This new protocol, the OKACOM Protocol on Hydrological Data Sharing for the Okavango River Basin (Protocol), is intended to help the three Member States better prepare themselves for extreme climatic events, such as floods and droughts. ${ }^{195}$ The Okavango Basin Steering Committee (OBSC) is the entity responsible for

187. MANAgING Shared Aquifer Resources in AFriCa: Third INTERnational CONFERENCE TRIPOLI 25-27 MAY 200841 (2010), available at http://unesdoc.unesco.org/ images $/ 0018 / 001884 / 188462 \mathrm{~m}$.pdf.

188. The Member States are Algeria, Tunisia, and Libya. Id.

189. Id.

190. Id.

191. Agreement Between the Governments of the Republic of Angola, the Republic of Botswana, and the Republic of Namibia on the Establishment of a Permanent Okavango River Basin Water Commission (OKACOM) art. 5, Sep. 15, 1994, archived at http://perma.cc/H7BV-XEJZ; the Member States are Angola, Botswana, and Namibia. Id.

192. Id.

193. Id.

194. 16th OKACOM Meeting, OKACOM, http://www.okacom.org/okacomnews/news/16th-okacom-meeting (last visited Jan. 10, 2014, archived at http://perma.cc/KFZ7-RQBF).

195. Id. 
the implementation of the Protocol. ${ }^{196}$ But, under the Protocol, each Member State shall be responsible for the installation, operation, and maintenance of hydrometeorological stations in its territory. ${ }^{197}$ The specific types of data required to be monitored pursuant to the Protocol include water levels, water discharge, water quality, sediment transport and meteorological data. ${ }^{198}$ More specifically, the Protocol also provides that the Member States shall share, on a daily basis, water level data collected from key hydrometric stations at the following sites: (a) in Angola, Menongue on the Cuebe, Mucundi on the Cubango and Cuito Cuanavale on the Cuito; (b) in Namibia, Rundu and Andara on the Okavango; and (c) in Botswana, Mohembo on the Okavango. ${ }^{199}$ The Member States are also required to share, on a quarterly basis, discharge data from all stations, calculated using rating curves from the previous hydrological year. ${ }^{200}$ Water quality data is also to be shared on a quarterly basis, and on an ad hoc basis as requested by the Member States. ${ }^{201}$ The Protocol specifies that the following parameters should be considered during an analysis of water quality: electrical conductivity, total dissolved solids, dissolved oxygen, $\mathrm{pH}$, phosphates; nitrates, fecal coliforms (in inhabited zones), total hardness, temperature, turbidity, total suspended solids, and chlorophyll $\mathrm{a}^{202}$ The Protocol requires that the sampling and analytical methods used to measure water quality be standardized among the Member States. ${ }^{203}$ With respect to sediment transport data, the Protocol mandates that such data be shared on an annual basis among the Member States. ${ }^{204}$ The Protocol also requires that meteorological data, including rainfall, evaporation and temperature data, be shared on an ad hoc basis. ${ }^{205}$ At the end of each hydrological year (defined in the Protocol as the period commencing each October 1 and ending each September 30), the Member States are given three months to prepare an annual hydrological report for such year, and the report is then distributed by OKASEC (The Secretariat). ${ }^{206}$ The Protocol also requires that early warning information with respect to important environmental indicators be shared among the Member States. OKACOM's Hydrological Task Force is required to provide OKASEC with "the best

196. OKACOM Protocol on Hydrological Data Sharing for the Okavango River Basin art. II, May 26, 2010 [hereinafter OKACOM Protocol], archived at http://perma.cc/3F2HYKQ6.

197. Id. art. IV.

198. Id. art. $\mathrm{V}$.

199. Id. art. VI.

200. Id. art VII.

201. Id. arts. VII-VIII.

202. Id. art. $\mathrm{LX}$.

203. Id. art. XII.

204. Id. art. X.

205. Id. art. XIIII.

206. Id. arts. I, XV. 
available information on floods, droughts and pollution magnitudes at different time and space scales. ${ }^{207}$ OKASEC is then required to channel such information to "decision making bodies and other public actors" in the Member States. ${ }^{208}$

\section{Southern African Development Community}

To achieve the objectives of the South African Development Community (SADC) Treaty, the SADC Treaty encourages, inter alia, the harmonization of political and socioeconomic policies of the Member States ${ }^{209}$ and the promotion of the coordination and harmonization of the international relations of the Member States. ${ }^{210}$ Furthermore, the Member States have agreed to cooperate in numerous areas, including in regards to natural resources and the environment. ${ }^{211}$ The objectives of the Watercourses Protocol include promoting the harmonization and monitoring of relevant legislation and policies concerning shared watercourses, as well as encouraging information exchange regarding shared watercourses management. ${ }^{212}$ The Watercourses Protocol also obligates the Member States to undertake to harmonize their water uses in the shared watercourses and to observe the objectives of regional integration and harmonization of their socioeconomic policies. ${ }^{213}$ In addition, the Member States agreed to verify that all necessary interventions in the shared watercourses are consistent with the sustainable development of all of the Watercourse States. ${ }^{214}$ For planned measures that may have a significant adverse impact upon other Watercourse States, the relevant Member States must engage in consultations (and, if necessary, negotiations on the possible effects of the planned measures on the shared watercourse) and exchange certain technical data and information, including the results of any environmental impact assessment. ${ }^{215}$

In terms of data exchange, the Member States are committed to exchanging available information and data concerning the hydrological,

207. Id. art. XIV.

208. Id. art. XIV.

209. The SADC Member States are Angola, Botswana, the Democratic Republic of the Congo, Lesotho, Madagascar, Malawi, Mauritius, Mozambique, Namibia, Seychelles, South Africa, Swaziland, Tanzania, Zambia, and Zimbabwe.

210. Treaty of the Southern African Development Community art. 5(2), Aug. 17, 1992 [hereinafter SADC Treaty], archived at http://perma.cc/N6JJ-FF5Z.

211. Id. art. 21 .

212. Protocol on Shared Watercourse Systems in the Southern African Development Community Region arts. 2(d), 2(e), 4(2)(b)(ii), Aug. 7, 2000 [hereinafter Watercourses Protocol], archived at http://perma.cc/KN5U-5Y6J.

213. Id. art. 2.

214. Id. art. 3(1).

215. Id. art 3(6). 
hydro-geological, water quality, meteorological and environmental condition of the shared watercourses in the SADC region. ${ }^{216}$ Furthermore, the Shared Watercourse Institutions are obligated to provide, on a regular basis or as required by the Water Sector Co-coordinating Unit, all of the information needed to assess the progress on implementing the Watercourses Protocol. ${ }^{217}$ Under the Protocol of Fisheries, the Member States agreed to exchange information needed to achieve the Protocol's objective of responsible and sustainable use of the aquatic resources and the aquatic ecosystems in the SADC region, as well as to cooperate in the exchange of information on the state of shared resources, levels of fishing effort, measures undertaken to monitor and control the exploitation of shared resources, any plans for new or expanded exploitation, and relevant research activities. ${ }^{218}$ Two or more Member States may collaborate to create mechanisms for cooperation and information sharing regarding shared resources. ${ }^{219}$ The Member States are also called upon to promote effective communication strategies with stakeholders in order to encourage the participative management of the aquatic resources and to publicize certain information, including the rationale and criteria behind decisions regarding total allowable catches, allocation of quotas, permits, licensing, and other rights to use the living aquatic resources. ${ }^{220}$

In addition, Member States are called upon to harmonize their legislation concerning the management of shared resources. ${ }^{221}$ The Member States have also agreed to make fishing and related activities by their nationals, illegal under the Protocol, illegal under their national laws and to establish region-wide comparable levels of penalties for illegal fishing by both non-SADC flag vessels and SADC flag vessels. ${ }^{222}$ In 2005 , the Governing Council decided to create a database of scientific organizations and individual scientists who work on fisheries, aquaculture, and other related activities in the region. ${ }^{223}$ The database is intended to promote the sharing of information between relevant organizations and scientists and individuals in the region. Currently, the database is limited to the Member States and their populations, but the goal is to eventually expand the database to a wider audience. ${ }^{224}$ In addition, the Governing Council has

216. Id. arts. 3(1), 3(6), 4(1).

217. Id. art. 5(3)(c).

218. Southern African Development Community Protocol on Fisheries arts. 3, 7(3)-(4), 18, Aug. 14, 2001, archived at http://perma.cc/32L6-ZKA6.

219. Id.

220. Id. art. 18.

221. Id. art. 8.

222. Id. arts. $8(1)-8(2), 8(4)(\mathrm{b})$.

223. Id. art. 8.

224. Database, Bay of Bengal Programme Inter-Governmental Organization, http://bobpigo.org/database.html (last visited Jan. 10, 2014, archived at http://perma.cc/65S5JEA). 
approved activities regarding capacity building related to fisheries data collection methodologies and stock assessment. ${ }^{225}$

\section{Bay of Bengal}

In 1995, the FAO developed a global Code of Conduct for Responsible Fisheries. ${ }^{226}$ Under the old FAO Bay of Bengal Program and continuing under the Bay of Bengal Programme-Inter-Governmental Organisation (BOBP-IGO), the Code of Conduct was translated into the languages of Bay of Bengal basin countries (Bengali, Dhivehi, Sinhalese, Thai, Oriva, Tamil, Telugu, Gujarati, Hindi and Marathi) in order to better engage the fishing community in the region. ${ }^{227}$ The BOBP-IGO is continuing this effort to translate the Code of Conduct and its Technical Guidelines into additional regional languages. ${ }^{228}$ The BOBP-IGO also intends to promote the Code of Conduct and its Technical Guidelines through workshops, seminars, and regional training courses in Member States, ${ }^{229}$ as well as distributing booklets directly to local fisherman. ${ }^{230}$ The regional training courses consist of theoretical sessions, field visits and interactions regarding the Code of Conduct and are targeted at mid-level and junior level fisheries officials in the Member States. ${ }^{231}$ In addition, information from the FAO's erstwhile Bay of Bengal Program is available online. ${ }^{232}$

225. Bay of Bengal Programme Inter-Governmental Organisation, Report of THE SiXTH MEETING OF THE GOVERNING COUNCIL 13 (2010), archived at http://perma.cc/CH4R-A3GL.

226. FOOD AND AGRIC. ORG. OF THE U.N., CODE OF CONDUCT FOR RESPONSIBLE FISHERIES, archived at http://perma.cc/GS8A-Q4NB.

227. See Programs, Bay of Bengal Programme InTER-GovernMENTAL ORGANIZATION, http://bobpigo.org/html_site/programs.htm (last visited Jan. 10, 2014, archived at $\mathrm{http}: / /$ perma.cc/YBA2-G8G9).

228. Id.

229. The Member States of the Bay of Bengal Inter-Governmental Organization on coastal fisheries are Bangladesh, India, the Maldives, and Sri Lanka. There have also been discussions for other countries in the Bay of Bengal region (such as Myanmar, Thailand, and Indonesia) to join the BOBP- IGO. Id.

230. Id.

231. See e.g., Regional Training Course on Code of Conduct for Responsible FISHERIES (2005), archived at http://perma.cc/QP7W-89W4.

232. Regional Fishery Bodies Summary Descriptions: Bay of Bengal Programme InterGovernmental Organization, FOOD AND AGRIC. ORG. OF THE U.N., $\mathrm{http} / / / \mathrm{www}$. fao.org/fishery/rfb/bobp_igo/en (last visited Jan. 10, 2014, archived at http://perma.cc/XYP8-R2LU). 


\section{Partnerships in Environmental Management for the Seas of East Asia}

One of the objectives of the Sustainable Development Strategy for the Seas of East Asia (SDS-SEA) ${ }^{233}$ is to mobilize governments, civil society and the private sector to use innovative communication methods. ${ }^{234}$ To achieve this aim and to enhance the dissemination of data related to coastal and marine environmental and resource management, the SDS-SEA encourages the use of local, national and regional networks to distribute information, the creation of online resource centers, the establishment of a news monitoring and quick response systems, and the establishment of partnerships with international agencies in order to strengthen technical skills related to information sharing. ${ }^{235}$ In addition, the Partnership Operating Arrangements call upon the Partners to "[s]trengthen communication and dialogue with each other regarding activities affecting the implementation of the SDS-SEA," and indicate that the Partners have the right " $[\mathrm{t}] \mathrm{o}$ participate in PEMSEA's knowledge sharing network."236 Additionally, the International Conference of the EAS Congress serves as a

233. Putrajaya Declaration of Regional Cooperation for the Sustainable Dev. OF THE SEAS OF E. ASIA 95 [hereinafter SDS-SEA], archived at http://perma.cc/S9GWBAKB.

234. Id. at 95. The PEMSEA Partner States who signed the Putrajaya Declaration are: Brunei Darussalam, Cambodia, China, the Democratic People's Republic of Korea, Indonesia, Japan, Malaysia, the Philippines, the Republic of Korea, Singapore, Thailand, and Vietnam. The signatories of the Haikou Agreement are: Cambodia, China, the Democratic People's Republic of Korea, Indonesia, Japan, Laos, the Philippines, the Republic of Korea, Singapore, Timor-Leste, and Vietnam. The Manila Declaration was signed by Cambodia, China, the Democratic People's Republic of Korea, Indonesia, Japan, Laos, the Philippines, the Republic of Korea, Singapore, Timor-Leste, and Vietnam. In addition to the Partner States, PEMSEA includes non-state Partners. These non-state partners include the Association of Southeast Asian Nations Centre for Biodiversity, the Coastal Management Center, Conservation International Philippines, the International Environmental Management of Enclosed Coastal Seas Center, the International Ocean Institute, the Intergovernmental Oceanographic Commission Sub- Commission for the Western Pacific, the International Union for the Conservation of Nature Asia Regional Office, the Korea Environment Institute, the Korea Maritime Institute, the Korea Ocean Research and Development Institute, the Northwest Pacific Action Plan, the Ocean Policy and Research Foundation, Oil Spill Response, the Plymouth Marine Laboratory, the PEMSEA Network of Local Governments for Sustainable Coastal Development, the Swedish Environmental Secretariat for Asia, the United Nations Development Programme (UNDP)/Global Environment Facility (GEF) Small Grants Programme, the United Nations Environment Programme (UNEP) Global Programme of Action, and the UNDP/GEF Yellow Sea Large Marine Ecosystem Project.

235. Id. at 91.

236. PaRTNERship OPERATING ARRANGements FOR THE IMPLEMENTATION OF THE Sustainable Dev. STRATEGY For THE SEAS OF E. Asia TT 9(c), 10(e) (2006), archived at http://perma.cc/C43Y-3QRZ (alterations added). 
forum to "[f]acilitat[e] knowledge exchange, advocacy and multistakeholder participation, through sessions, workshops, side events and exhibitions, etc.",237

\section{South China Seas}

The United Nations Convention on the Law of the Sea ${ }^{238}$ obligates Member States ${ }^{239}$ to cooperate directly and through competent international organizations to exchange information and data acquired about pollution of the marine environment. ${ }^{240}$ In addition, under the Declaration on the Conduct of the Parties in the South China Sea, the Parties agreed to share data on a voluntary basis. ${ }^{241}$ However, such data sharing is to begin "pending the peaceful settlement of territorial and jurisdictional disputes." ${ }^{242}$ The ASEAN Declaration on the South China Sea simply states that the Parties shall resolve to explore the possibilities of cooperation in the South China Sea. ${ }^{243}$ It does, however, urge the Parties to apply the principles contained in the Treaty of Amity and Cooperation in Southeast Asia as the basis for establishing a code of international conduct over the South China Sea. ${ }^{244}$ The Treaty of Amity and Cooperation in Southeast Asia states that the Contracting Parties shall "strive to achieve the closest cooperation on the widest scale and shall seek to provide assistance to one another in the form of training and research facilities in the social, cultural, technical, scientific and administrative fields." ${ }^{245}$ The Treaty further states that the Contracting Parties shall "maintain regular contacts and consultations with one another on international and regional matters with a

237. Id. $\uparrow 22$ (b) (alterations added).

238. United Nations Convention on the Law of the Sea art. 200, Dec. 10, 1982, 1833 U.N.T.S. 561 [hereinafter UNCLOS].

239. The UNCLOS Member States that border the South China Sea are: Brunei, Indonesia, Malaysia, Myanmar, Laos, China, Philippines, Thailand, Vietnam, and Singapore. Cambodia and Thailand have signed UNCLOS, but have not yet ratified the Treaty. The Parties to the Declaration on the Conduct of the Parties in the South China Sea are Brunei, Cambodia, Indonesia, Laos, Malaysia, Myanmar, Philippines, Singapore, Thailand, Vietnam, and China. The Parties to the ASEAN Declaration on the South China Sea are Brunei, Indonesia, Malaysia, Philippines, Singapore, and Thailand. The Contracting Parties of the Treaty of Amity and Cooperation in Southeast Asia, as amended, which border the South China Sea are: Brunei, Cambodia, Indonesia, Laos, Malaysia, Myanmar, Philippines, Singapore, Thailand, Vietnam, and China.

240. Id. art. 64(1).

241. Declaration of the Conduct of Parties in the South China Sea Declaration 5(d), Nov. 4, 2002 [hereinafter ASEAN Declaration], archived at http://perma.cc/PGJ7-B6BQ.

242. Id.

243. Id.

244. Id. at declarations 1,4 .

245. Treaty of Amity and Cooperation in Southeast Asia art. 8, Feb. 26, 1976 [hereinafter Treaty of Amity], archived at http://perma.cc/D5YP-VCVY. 
view to coordinating their views actions [sic] and policies."246

\section{Western and Central Pacific Fisheries Commission}

Each Commission Member, Cooperating Non-Member and Participating Territory (CCM) must submit an annual report containing certain statistical, biological and other data as required. ${ }^{247}$ Part 1 of the Annual Report, which is submitted to the SC, includes information for each $\mathrm{CCM}$ on: (a) fisheries information; (b) background (e.g., historical description of national fisheries); (c) flag state reporting that details the activities of national fleets, listed by gear types, in the Convention Area (including trends in each fishery related to changes in fishing patterns, fleet operations, target species, and size composition); (d) coastal state reporting that details activities by foreign and domestic fleets in waters under national jurisdiction (including trends in each fishery related to changes in fishing patterns, fleet operations, target species, and size composition); (e) socioeconomic factors; (f) disposal of catch (such as fresh or frozen) and market destination (export of import); (g) onshore developments (such as processing plants or support facilities); (h) prospects of the fishery (such as long-term viability and whether the fisheries are expanding or contracting); (i) the status of tuna fishery data collection systems (including information on log sheet data collection and verification, the observer program, the port sampling program, and unloading and transshipment); and (j) research activities focused on both target and non-target species. ${ }^{248}$ For the fisheries information, each CCM is required to provide data for its national fleet in the Convention Area, including information on, among other requirements: annual catch and effort estimates, number of vessels, annual distribution of target species catch and effort, and estimated annual coverage of operational catch/effort, port sampling and observer data. ${ }^{249}$ This

246. Id. art. 9.

247. Convention on the Conservation and Management of High Migratory Fish Stocks in the Western and Central Pacific Ocean arts 2(a), 23, Sep. 5, 2000; WCPFC QUARTERLY REPORT, FIRST QUARTER 2010 (2010), archived at http://perma.cc/G9GQ-XKAN. The Contracting Parties are Australia, China, Canada, the Cook Islands, the European Community, the Federated States of Micronesia, Fiji, France, Japan, Kiribati, South Korea, the Republic of the Marshall Islands, Nauru, New Zealand, Niue, Palau, Papua New Guinea, Philippines, Samoa, the Solomon Islands, Chinese Taipei (as a fishing entity), Tonga, Tuvalu, the United States, and Vanuatu. In addition, American Samoa, the Commonwealth of the Northern Mariana Islands, French Polynesia, Guam, New Caledonia, Tokelau, and Wallis and Fatuna are Participating Territories. Belize, Indonesia, Senegal, Mexico, El Salvador, Ecuador, and Vietnam are Cooperating Non-Members.

248. THE COMM'N FOR THE CONSERVATION AND MgMt. OF Highly Migratory Fish Stocks IN THE W. AND CenT. PAC. OCEAN (2012), archived at http://perma.cc/Q9MQDKEC; Convention on the Conservation and Management of High Migratory Fish Stocks in the Western and Central Pacific Ocean, supra note 247, art. 23. 
information must be broken down by gear type (such as longline, purse seine, pole-and-line, troll, handline, ringnet, and driftnet). ${ }^{250}$

In Part 2 of the Annual Report, which is submitted to the TCC, the CCMs report on their implementation of the Commission Vessel Monitoring Systems (CMMs), as well as monitoring and inspection activities, surveillance activities, investigations and prosecution activities, and other relevant information. ${ }^{251}$ Monitoring and inspection activities includes the vessel monitoring system, transshipments inspections, at-sea inspections, port inspections, observer monitoring, monitoring of trade and domestic distribution of highly migratory fish species, inspections of domestic-only vessels, and high seas boarding and inspection of flag vessels. ${ }^{252}$ Part 1 Reports are posted on the Western and Central Pacific Fisheries Commission (WCPFC) website, but Part 2 Reports are classified as confidential and only available to other $\mathrm{CCMs} .{ }^{253}$

Under article 24, each CCM must produce a Record of Fishing Vessels that are entitled to fly its flag and are authorized to fish, beyond the areas of national jurisdiction, in the Convention Area and submit it to the Commission. ${ }^{254}$ The Commission has established a Vessel Monitoring System (VMS) that requires each vessel that fishes in certain parts of the high seas in the Convention Area (south of $20^{\circ} \mathrm{N}$ and above $20^{\circ} \mathrm{N}$, east of $175^{\circ} \mathrm{E}$ ) to use near real-time satellite position-fixing transmitters (i.e., a mobile transceiver unit/automatic location communicator (MTU/ALC)) in order to track the positions and movements of fishing vessels. ${ }^{255}$ If a vessel is initially fishing in the covered area but then moves north of $20^{\circ} \mathrm{N}$ and west of $175^{\circ} \mathrm{E}$, it still needs to keep its MTU/ALC activated. ${ }^{256}$ Generally, vessels report their position to the Commission automatically. ${ }^{257}$ Automated alerts have also been established to alert the Commission when vessels enter or exit the high seas of the Convention Area. ${ }^{258}$ If a vessel is fishing in waters under the national jurisdiction of another member of the Commission (besides its flag state), it must comply with the requirements of that coastal state in regards to the use of near real-time satellite position-

250. Id.

251. Id.

252. W. \& CENT. PAC. Fisheries COMm'N, REVISED TEMPLATE FOR THE ANNUAL REPORT (PART 2) (2009), archived at

http://perma.cc/3YM6-QGLJ; Convention on the Conservation and Management of High Migratory Fish Stocks in the Western and Central Pacific Ocean, supra note 247, art. 23.

253. REVISED TEMPLATE FOR THE ANNUAL RePORT (PART 2), supra note 252.

254. Convention on the Conservation and Management of High Migratory Fish Stocks in the Western and Central Pacific Ocean, supra note 247, art. 24.

255. Convention on the Conservation and Management of High Migratory Fish Stocks in the Western and Central Pacific Ocean, supra note 247, art. 24(8).

256. Id.

257. Id.

258. Id. 
fixing transmitters. ${ }^{259}$ The Commission enacted security measures to protect access to the data. ${ }^{260}$ The flag states are obligated to ensure that their fishing vessels comply with the VMS requirements. ${ }^{261}$ The Forum Fisheries Agency (FFA) also has a VMS program, and fishing vessels on the high seas have the option of reporting data to the Commission through the FFA's VMS. ${ }^{262}$ In addition, any CCM can request that the waters under its national jurisdiction be included in the Commission's VMS (with New Zealand being the first county to sign up for this option). ${ }^{263}$

The WCPFC has entered into Data Exchange Agreements with the SPC in regards to aggregated catch and effort data and with the InterAmerican Tropical Tuna Commission (IATTC) in regarding to operationallevel tuna fisheries data (such as catch and effort, observer, unloading, transshipment and port inspection data), aggregated catch and effort data, and other relevant monitoring, control, surveillance, inspection and enforcement data. ${ }^{264}$ The Commission has also adopted rules governing the protection and dissemination of data that is compiled by the WCPFC..$^{265}$

\section{The Mekong}

The Mekong Basin's ${ }^{266}$ water resources have the ability to support

\section{Id.}

260. Id.

261. Id.

262. Id.

263. Conservation and Management Measures, W. \& CENT. PAC. Fisheries COMM'N, http://www.wcpfc.int/conservation-and-management-measures (last updated Dec. 15, 2013, archived at http://perma.cc/KWV8-L7V9); W. \& CENT. PAC. FISHERIES COMM'N, COMMISSION VMS STANDARD OPERATING PROCEDURES (SOPS) (2010), archived at http://perma.cc/U96A-XKZB; Convention on the Conservation and Management of High Migratory Fish Stocks in the Western and Central Pacific Ocean, supra note 247, art. 24 (8)(10); WCPFC QUARTERLY REPORT, FIRST QUARTER 2010 (2010), archived at http://perma.cc/P7SH-CEJK.

264. Data Exchange Agreement Between the Western and Central Pacific Fisheries Commission and The Secretariat of the Pacific Community, Aug. 27, 2009, archived at http://perma.cc/4A2A-YD27; Memorandum of Cooperation on the Exchange and Release of Data between the Commission for the Conservation and Management of Highly Migratory Fish Stocks in the Westem and Central Pacific Ocean and the Inter-American Tropical Tuna Commission, Dec. 11, 2009, archived at $\mathrm{http} / / /$ perma.cc/ZBR2-KCM9.

265. Rules and Procedures for the Protection, Access to, and Dissemination of Data Compiled by the Commission, Dec. 2007, archived at http://perma.cc/8YTJ-AUA7.

266. Mekong Physical Characteristics: 795,000 sq. $\mathrm{km}$ in area. River length $4,200 \mathrm{~km}$. Basin Annual internal per capital water resources of basin countries ranges from 1,845 cubic meters in Thailand to 50,392 cubic meters in Laos (World Resources Institute, 2000). Basin climate is predominately tropical with significant seasonal rainfall. Socio-Political Characteristics: Basin shared by Cambodia, China, Laos, Myanmar, Thailand, and Vietnam. Low or medium levels of development in basin countries (United Nations Development Programme, 2000). Agriculture, particularly subsistence agriculture, the dominant economic 
economic growth through irrigation, hydropower, navigation, water supply and tourism. Equitable sharing of the water resources and sustainable development of the natural resources in the Basin becomes most critical during the dry season. ${ }^{267}$

Key to reaching an overall framework agreement in 1995 was the need to find acceptable language that provided both a sense of good faith and cooperation, and the assurances that no party would be disadvantaged under its provisions in light of the doctrine of sovereign equality. ${ }^{268}$ Efforts to promote sustainable water management in the Mekong River Basin and protection for the environment, aquatic life and the ecological balance of the basin subsequently received a major boost in the form of an \$11 million influx of funding from the Global Environment Facility. ${ }^{269}$ The Water Utilization Project (WUP) funded by the grant supported the Mekong River Commission in developing an integrated and comprehensive Basin hydrologic modelling package, and a functional and integrated knowledge base on water and related resources, and in using these tools to establish "Rules," one of five major goals. ${ }^{270}$ The first Rules developed using an "interest based" negotiation approach were the "Procedures for Data and Information Exchange and Sharing" dated November 1, 2001. ${ }^{271}$ The approach taken was essentially to establish a framework agreement and a committee and then leave implementation to the committee. ${ }^{272}$

\section{The Columbia}

The Columbia River is one of a number of key international watercourses shared by Canada and the United States where Canada is generally the upstream watercourse state and the US is generally the downstream watercourse state. Stretching 1,952 kilometers, the Columbia River is the fourth largest river in North America and the Columbia River basin covers 640,000 square kilometers of territory in Canada and the

activity in the basin. Major conflict and upheaval over much of the last 50 years occurred in the basin although recent comparative stability has been re-established. Historical Development Cooperation first began in the late 1950s between Cambodia, Laos, South Vietnam, and Thailand, with initial efforts concentrated on data collection and exchange (Schaaf and Fifield, 1963). Cooperative committee with a narrow focus was established between these four countries in 1957. Mekong River Commission (MRC) was established in 1995 between Cambodia, Laos, Thailand, and Vietnam to replace earlier committee (Mekong River Commission, 1995).

267. Agreement on the Cooperation for the Sustainable Development of the Mekong River Basin Apr. 5, 1995, archived at http://perma.cc/A2LC-PT3X.

268. R.K. Paisley, Adversaries into Partners: International Water Law and the Equitable Sharing of Downstream Benefits, 3 Melbourne J. of Int'l L. (2002).

269. Id.

270. Id.

271. See Mekong River Commission for Sustainable Development, Procedures for Data and Information Exchange and Sharing, archived at http://perma.cc/ZEH8-J7WW.

272. Id. 
United States. $^{273}$

Much of the data sharing under the Columbia River Treaty is performed by the Permanent Engineering Board. ${ }^{274}$ The Columbia River Treaty established the Permanent Engineering Board, consisting of four members - two appointed by the United States and two appointed by Canada. ${ }^{275}$ The Permanent Engineering Board is tasked with the following duties:

- Assemble records of the flows of the Columbia River and the Kootenay River at the Canada-United States boundary;

- Report to the United States and Canada whenever there is substantial deviation from the hydroelectric and flood control operating plans and, if appropriate, include in the report recommendations for remedial action and compensatory adjustments;

- Assist in reconciling differences concerning technical or operational matters that may arise between the United States and Canadian Entities;

- Make periodic inspections and require reports from the United States and Canadian Entities in order to ensure that the objectives of the Columbia River Treaty are being met;

- Make reports, at least once a year, to the United States and Canada of the results being achieved under the Columbia River Treaty and make special reports concerning any matter which it considers should be brought to the countries' attention; and

- Investigate and report with respect to any other matter that comes within the scope of the Columbia River Treaty, at the request of either the United States or Canada. ${ }^{276}$

The Permanent Engineering Board must comply with directions relating to its administration and procedures that are agreed upon by the

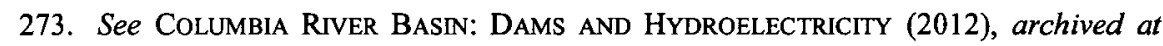
http://perma.cc/J58L-6P3H.

274. Treaty Relating to Cooperative Development of the Water Resources of the Columbia River Basin (with Annexes), U.S.-Can., art. XV, Jan. 17, 1961[hereinafter Columbia River Treaty], archived at http://perma.cc/DT5M-VE4C.

275. Id.

276. Id:; see also Permanent Engineering Board, Columbia River Treaty, U.S. ARMY CORPS OF ENGINEERS COLUMBIA BASIN WATER MaNAGEMENT, http://www.nwd-wc.usace.army.mil/PB/PEB_08/peb.htm (last updated Sep. 4, 2008, archived at http://perma.cc/5KDC-3AWE). 
United States and Canada. ${ }^{277}$ The key subsidiary agreement to the Treaty governing data and information and exchange is entitled: "Terms of Reference for the Columbia River Treaty Hydrometeorological Committee" and is dated May 20,1968. ${ }^{278}$ The approach taken was essentially to establish a framework agreement and a committee and then leave implementation to the committee. . $^{279}$

\section{Africa Generally}

"With the exception of island states, every African country has territory in at least one transboundary river basin and transboundary river basins cover $62 \%$ of Africa's total land area. ${ }^{280}$ Therefore, Africa is a region of international drainage basins and provides, based on the authors' conclusions, the following lessons on sharing data and information in international waters situations:

- Responsibilities for data collection and analysis for transboundary water resources management in Africa are typically divided up among different levels of government. As a result, a division of labor-between the member countries responsible for collecting and analyzing data in their own territories and an international commission responsible for setting standards and responsible for coordinated basin wide analysis-probably offers the best prospect for success.

- The methods used to collect data in different African countries do not always appear to be in line with international standards. This often means that the information derived from the data cannot be directly compared with data from neighboring countries.

277. Permanent Engineering Board, Columbia River Treaty, U.S. ARMY CORPS OF ENGINEERS COLUMBIA BASIN WATER MANAGEMENT, http://www.nwd-wc.usace.army.mil/ PB/PEB_08/peb.htm (last updated Sep. 4, 2008, archived at http://perma.cc/5KDC-3AWE).

278. See Columbia River TREATY Hydrometeorological COMMITTEe, 2001 ANNUAL REPORT app. B (2002), archived at http://perma.cc/VLM9-KDMS.

279. Id.

280. Jonathan Lautze \& Mark Giordano, Transboundary Water Law in Africa: Development, Nature and Geography, 45 NAT. RESOURCES J. 1053 (2005); see also Malte Grossman, Cooperation on Africa's International Waterbodies: Information Needs and the Role of Information Sharing, in TRANSBOUNDARY WATER MANAGEMENT IN AFRICA: Challenges fOR Development CoOperation 173 (Waltina Scheumann \& Susanne Neubert eds., 2006). The former article explores the instruments that basin organizations in Africa have assumed to facilitate the transmission of information. It concludes with lessons to be drawn for development cooperation. The latter article focuses more on documenting and analyzing a large body of transboundary water agreements relating to Africa with a view towards providing guidance for future institutional development. 
- In supporting transboundary water resources management in Africa, the transaction costs involved in information transmission should be carefully considered. The widespread "what we need is more data" paradigm must give way to the efforts of specifying the information required to make management decisions.

- Synergy with other information-generating initiatives should be sought. Close coordination with other national or international initiatives is a good way to make optimal use of synergy. Targeted co-financing of relevant programs is a good way to harness synergy potentials.

- There is an important lesson to be learned regarding the play of tensions between various requirements concerning the level of public accessibility of information for International Waters Resource Management (IWRM). The best practices of IWRM are grounded in transparent mechanisms for the allocation, protection, and basic supply of scarce water resources. Successful mechanisms are best ensured through clear-cut institutional arrangements, designed to set the stage for planning and management at the lowest possible level, and with the participation of all stakeholders. Participation requires public accessibility of information. Publication of information may prove beneficial to the political and civil discourse over possible riparian cooperation. On the other hand, transboundary water resources management is, for the most part, a governmental task with political accountability. If riparian states withhold information for strategic reasons, creation of a shared information base (i.e. one that is not public but accessible only to the parties) may constitute an important trust-building measure for initiating transboundary negotiations.

- Any successful information and decision-support system should be perceived as "owned" by the riparian countries concerned.

- It is essential that both the database and methods used for calculation of data and information for IWRM are transparent and inspire confidence. This requires all concerned riparian states to be involved "at eye level" in the specification and development of the models. There should also be consensus on assumptions, methods, and technical descriptions.

- It is also essential that the set of instruments used to collect data and information are maintained and developed over the long term. This means that due consideration must be given to the institutional, financial, and technical aspects. 


\section{CONCLUSIONS: AN IDEALIZED MODEL DATA AND INFORMATION SHARING AND EXCHANGE AGREEMENT FOR INTERNATIONAL WATERS}

This paper has critically identified and reviewed one aspect of good governance in the international waters context: data and information sharing and exchange. The following eight points identify the possible scope and content of an idealized model data and information sharing and exchange agreement for transboundary international waters.

- Types of data and information: transboundary water resources management usually requires interventions to integrate socio-economic, environmental and technical/engineering issues and, hence, requires broader types of data and information spanning a potentially wide spectrum of thematic categories.

- Custodianship of Data/Information: the data/information that are being compiled from various sources for the planning/implementation of various current and possible future projects/programs should be systematically archived and made available for use by countries in their cooperative management. This may require a central database of "mutually agreed" data and information, which is maintained and managed by an appropriately mandated institution, which becomes the custodian of the database.

- Access to "third parties": an important question to be addressed by any agreement regarding data and information sharing and exchange refers to provision of access to potential users other than governments of the riparian states entering into the agreement. Should the agreement limit its scope to governing exchange and sharing of data and information among the riparian states only? Or should it also deal with the question under what circumstances and modalities should access to data/information be granted to "third parties," which may include academic/research institutions, NGOs, UN agencies, private institutions?

- Finance and costs: What are the circumstances under which data and information should be paid for, and by whom? A good starting point could be whereby exchange of readily available data would proceed at no cost to the requesting riparian state. The challenge here is that it may be difficult to reach consensus on what is meant by the term "readily available." Depending upon whether "third" party access is provided for, the agreement should probably also have provisions on how access is granted to such "outside" users.

- Data standards and compliance: this refers to the various standards that are potentially relevant in handling data/information sets included in the 
agreement. While the agreement may not deal with specific details of what standards are to be used, it should probably clarify how these standards are to be set, and who shall be responsible for quality assurance of the data/information for standardizing data formats and similar issues.

- Implementation arrangements: while the issue of managing and maintaining the "mutually agreed" data and information is largely addressed under "custodianship," discussed above, the agreement needs to address the issue of how the agreement is to be implemented. Important relevant issues most likely include monitoring, verification, compliance, finance and dispute resolution.

- Adaptivity: How can the agreement be "adaptive" with regard to emerging technologies?

- Sustainability: How can "sustainability," including financial sustainability of the agreement, be ensured? What is the fuel that will keep it running and maintain the parties' interests in continuing to implement it, and indeed modify and enhance it? This needs to be achieved by ensuring that the agreement adequately addresses the fundamental incentives of the parties. 
